\title{
Recombinant therapeutic proteins produced in plants: towards engineering of human-type $\mathbf{0}$ - and $\mathrm{N}$-glycosylation
}

\author{
KRUNO VUKUŠIĆ 1 \\ SANDRA ŠIKIĆ ${ }^{2}$ \\ BILJANA BALEN ${ }^{3 *}$ \\ ${ }^{1}$ Laboratory of cell biophysics, Division of Molecular \\ Biology, Ruđer Bošković Institute, Bijenička cesta 54, \\ HR-10000, Zagreb, Croatia \\ 2 Department of Ecology, Dr. Andrija Štampar Institute \\ of Public Health, Mirogojska cesta 16, HR-10000, \\ Zagreb, Croatia \\ ${ }^{3}$ Division of Molecular Biology, Faculty of Science, \\ University of Zagreb, Horvatovac 102a, HR-10000 \\ Zagreb, Croatia \\ *Correspondence: \\ Assoc. Prof. Biljana Balen \\ E-mail:bbalen@biol.pmf.hr

\section{Abbreviations:} \\ AGPS - arabinogalactan proteins \\ $\mathrm{CHO}$ - Chinese hamster ovary \\ EGFP - enhanced green fluorescent protein \\ ER - endoplasmic reticulum \\ FDA - Food and Drug Administration \\ GA - Golgi apparatus \\ GCD - glucocerebrosidase \\ hEPO - human erythropoietin \\ HGRPS - Hyp-rich glycoproteins \\ Hyl - hydroxylysine \\ Hyp - hydroxyproline \\ hTF - human transferrin \\ IDUA $-\alpha$-L-iduronidase \\ mAb - monoclonal antibody \\ MUC1 - mucin 1 glycoprotein \\ PEG - polyethylene glycol \\ P4H - prolyl 4-hydroxylase \\ PTM - post-translational modification \\ tobacco BY-2 cell culture - tobacco cultivar \\ Bright Yellow - 2
}

Key words: plant molecular farming, glycoengineering, $\mathrm{N}$-glycosylation, $\mathrm{O}$-glycosylation

Received December 23, 2015.

Revised April 25, 2016.

Accepted May 13, 2016

\begin{abstract}
Background and Purpose: Recombinant DNA technology has allowed expression of different heterologous proteins in many host systems, ranging from prokaryotic to eukaryotic organisms. Therapeutic properties of recombinant proteins are very often affected by the composition and heterogeneity of their glycans. Conventional expression systems for recombinant pharmaceuticals typically do not address this problem and result with products that contain a mixture of glycoforms that are neither identical to human glycans nor optimized for enhanced biological activity. Over the last decade plants have been developed as production platforms for recombinant proteins with pharmaceutical or industrial applications. Namely, plant expression systems contain very small differences in the post-translational modifications, mainly glycosylation, which can partly be overpowered by glycoengineering, whose goal is production of recombinant proteins with highly homogenous glycosylation that closely resembles the native system. This review attempts to present current accomplishments in the production of plant-derived glycoconjugates with humanized $N$ - and $O$-glycans.
\end{abstract}

Materials and Methods: Main goal of $N$-glycoengineering is to reduce or eliminate plant-specific $\mathrm{N}$-glycans, and at the same time to introduce mammalian-specific $N$-glycans through the several approaches. The easiest way is to change intracellular targeting of plant-made recombinant proteins and to ensure their retention in the ER; next approach is to eliminate the addition of plant-specific glycans; while the final step is engineering the plant glycosylation pathway to introduce mammalian glycotransferases into plants with generation of biantennary and multi-antennary structures on complex $N$-glycans. Due to significant differences in O-glycosylation between humans and plants, different approaches to engineering of $O$-glycosylation have been taken. Besides having their typical O-glycoslyation on Hyp-residues, plants in general miss the machinery for production of mammalian-type O-glycosylation. Attempts have been made to mimic mammalian O-glycosylation in plants, specifically the mucin-type addition of GalNAc residues.

Result: Efficient generation of bisected tetraantennary complex $N$-glycans without typical plant glycoepitopes on human erythropoietin ( $D E P O$ ) and human transferrin (hTF) was obtained in Nicotiana benthamiana plants, thus demonstrating generation of recombinant proteins with human-type N-glycosylation at great uniformity. As for the O-glycosylation, attempts to produce mucin-type O-GalNAc and disialylated core $1 O$ linked glycan structures on hEPO in $N$. benthamiana transgenic plants proved to be successful. Moreover, although small amounts of Hyp residues were found on recombinant EPO, no plant-specific O-glycans were de- 
tected, which demonstrates that plants are eligible candidates for production of recombinant therapeutics with fully humanized $O$ - and $N$-glycans.

Conclusion: Plants and methods of plant molecular farming offer a powerful expression platform for the production of a variety of recombinant proteins, which show similar, or even higher, biological activity then protein or native homologs in cultured mammalian cells currently used for largescale production.

\section{INTRODUCTION}

R ecombinant DNA technology has allowed expression Rof different heterologous proteins in many host systems, ranging from prokaryotic to eukaryotic organisms. Recombinant microbial systems (mainly bacteria Escherichia coli) are in use for the last 30 years and they are now very important source of industrial and medicinal proteins $(1,2,3)$. Yet, some classes of proteins cannot be produced in microbial systems due to low product quality, particularly if post-translational processing is needed for stability and activity of proteins. Thus, yeast cells, insect cell lines and mammalian cell cultures have been utilized for eukaryotic protein production $(4,5)$, although the implementation of each of these expression systems has its shortcomings $(6,7)$. Interestingly, these conventional expression systems typically do not address the problem of glycan heterogeneity albeit they result with products that contain a mixture of glycoforms that are neither identical to human glycans nor optimized for enhanced biological activity (8).

Over the last decade plants have been developed as recombinant protein production systems in a methodology called plant molecular farming (9). This methodology exploits transgenic plants and plant cell cultures as production systems for recombinant proteins with commercial, industrial or pharmaceutical applications. Compared to conventional expression systems plant molecular farming has many advantages. Production costs are significantly lower than those of cell-based production systems $(10,11)$ and plants are capable of performing eukaryotic-like post-translational modifications (PTMs) $(12,13)$, which allow the production of recombinant humanized molecules that are highly similar or even identical to the native protein $(14,15)$. In addition, engineering of plant expression systems enables the production of recombinant proteins with specific and controlled modifications, which provide additional benefit for plant-made products that cannot be replicated in bacterial or yeast expression systems $(6,16,17)$. Plants are particularly well suited for production of therapeutic recombinant products such as antibodies and vaccines $(18,19)$, since generally they do not carry human pathogens that can be associated with mammalian expression systems.

The main limitations of plant expression systems are differences in the glycosylation pathway, namely complex processing of glycan side-chains, including some hostspecific modifications that do not occur in humans and vice versa $(20,21,22)$. These imperfections can partly be overpowered by glycoengineering, whose goal is production of recombinant proteins with highly homogenous glycosylation that closely resembles the native system. The aim of this paper is to review the accomplishments of the attempts in production of plant-derived glycoconjugates with humanized $\mathrm{N}$ - and $\mathrm{O}$-glycans with the emphasis on several approaches: (i) use of C-terminal endoplasmic reticulum (ER) retention motif to prevent formation of plant-specific complex $\mathrm{N}$-glycans and/or O-glycans; (ii) inactivation of plant-specific glycosyltransferases; and (iii) introduction of human-specific glycosyltransferases to obtain humanized $\mathrm{N}$ - or O-glycans.

\section{OVERVIEW OF POST-TRANSLATIONAL MODIFICATION OF PLANT PROTEINS}

Glycosylation is the best-studied PTM of plant-made recombinant proteins but other types of protein processing and modification also co-occur and are important in production of high-quality recombinant proteins. After translation, the majority of plant proteins experience covalent modifications that change their tertiary and quaternary structures. PTMs are known to affect almost every aspect of protein activity, from protein function, localization, stability to interaction dynamics with other molecules (23). These modifications are very diverse, and they range from very simple chemical changes, such as the addition of small phosphate or acetate functional groups, to complex changes that are enormous in size and by mass exceed protein part (e.g. proteoglycans) $(24,25)$. A single type of modification or various combinations of PTMs can modify one protein. These modifications may be influenced by developmental stage, location or by some biotic or abiotic factors, mainly by stress and disease state of a plant (23). In all this cases, PTMs are highly regulated and specific to cellular requirements. In addition, some PTMs (cleavage of a signal peptide or glycosylation) are permanent changes of a protein structure, unlike others (phosphorylation) that are rapidly reversed. The relationship between structure and function is understood for many PTMs but remains incomplete for others, particularly in the case of complex PTMs, such as glycosylation (26). To conclude, PTMs represent mechanism for exponential diversification of a genome and act to extend the repertoire of proteins available to facilitate the complex interactions of proteins in multiple cellular pathways (23).

\section{N-GLYCOSYLATION}

\section{Differences of $\mathbf{N}$-glycosylation between humans and plants}

Glycosylation is a very prominent PTM in all eukaryotic cells. It is estimated that at least $50 \%$ and as high as 
$70 \%$ of human proteins are glycosylated (27). Moreover, $40 \%$ of the currently approved protein therapeutics as well as many other clinically useful proteins are glycosylated (28). In N-glycosylation, complex glycan chains are covalently attached to the amide nitrogen in the side chain of asparagine (Asn) residues on newly synthesized proteins. This modification strongly influences many properties of proteins, including folding, self-association, resistance to proteolytic degradation, solubility, protein sorting within the cell, volume and charge of glycoproteins and all that can be important for efficiency of ligand binding and conformational stability or protein half-life (29). Thus, the ability of recombinant expression systems to efficiently and accurately glycosylate proteins is vital to the production of efficient recombinant protein that will be used in clinical applications.

The N-glycosylation pathway in plants is highly homologous with other eukaryotic systems, including the site-occupancy, frequency of glycosylation and the structure and composition of the core high-mannose type glycan added in the ER (23). Glycosylation pathway starts when the core glycan structure is assembled in the ER as a mannose (Man)-rich lipid precursor, Glc 3 Man-
${ }_{9} \mathrm{GlcNAc}_{2}$, which is transferred by oligosaccharyltransferase complex to the Asn residue in the $\mathrm{N}$-glycosylation consensus sequence Asn-X-Ser/Thr (where $\mathrm{X}$ is any amino acid except Pro) $(30,31)$. Common N-glycan core structure $\mathrm{Man}_{3} \mathrm{GlcNAc}_{2}$ is composed of N,N'-diacetylglucosamine dimmer (GlcNAc-GlcNAc) called chitobiose, a $\beta$-Man residue attached to the chitobiose and two $\alpha$ Man residues linked to hydroxyl 3 and 6 of the $\beta$-Man $(32,33)$. Once transferred onto the nascent protein and while the glycoprotein is transported along the secretory pathway, the $\mathrm{N}$-glycan undergoes several maturation steps. The first step includes the removal of three glucose (Glc) residues in ER (34) to generate high-mannose type $\mathrm{N}$-glycans that are common to human, animals and plants (33). Trimming of Man residues occurs after the glycoprotein is transported to Golgi apparatus (GA), which yields oligomannose glycan structures (35). These structures are further extended with GlcNAc residues to form a base for complex-type $\mathrm{N}$-glycans (36). These Nglycans differ between humans and plants (Figure 1), as will be described below. Third type of N-glycans are called hybrid N-glycans, in which glycoepitopes of $\alpha(1,3)$ fucose (Fuc) and/or $\beta(1,2)$-xylose (Xyl) are linked to the GlcNAcMan $_{5}-$ GlcNAc $_{2}$ core.

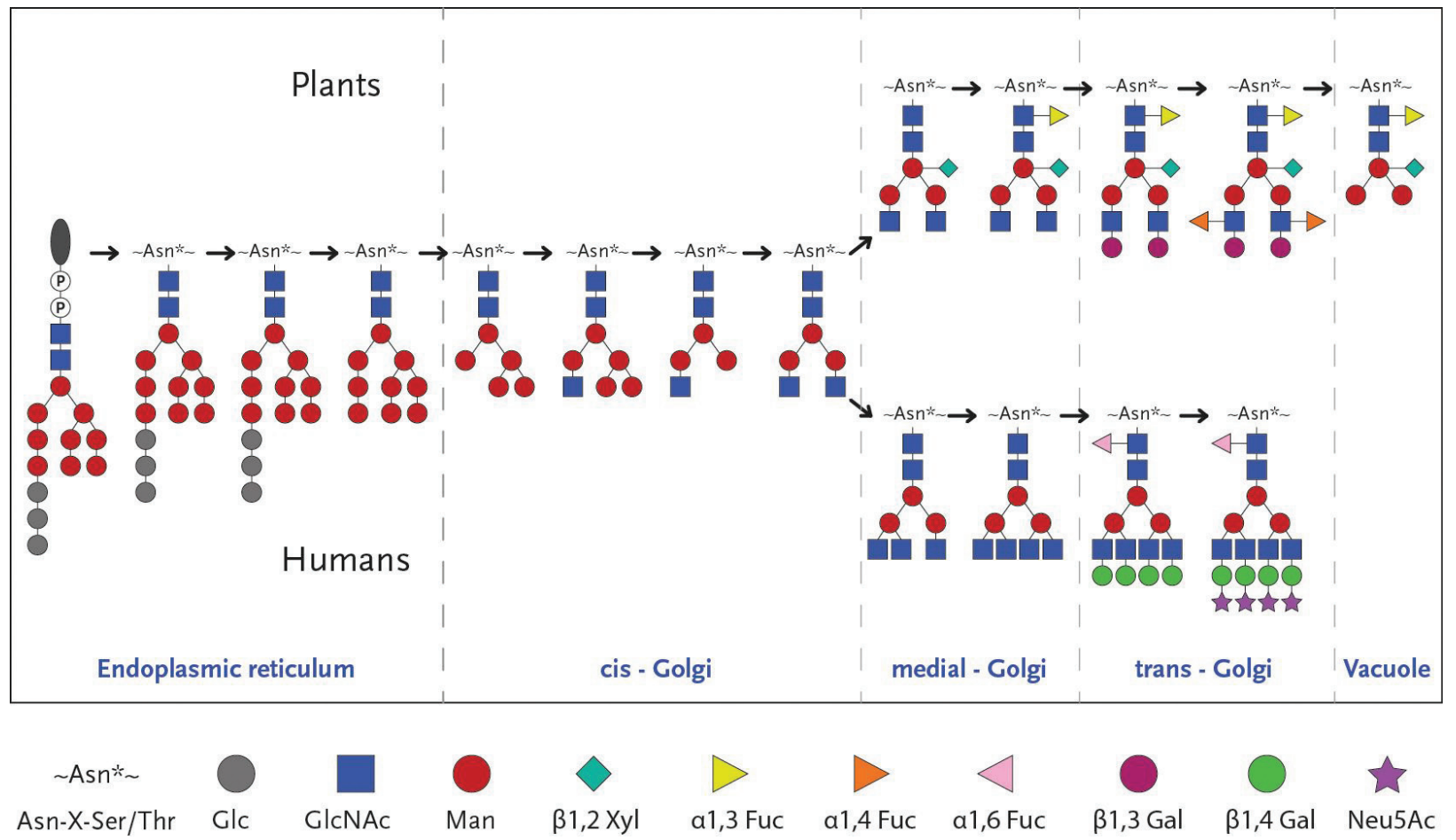

Figure 1. Biosynthesis and processing of $N$-glycans in plant and human cells. An oligosaccharide precursor assembled onto a lipid carrier is transferred on specific Asn residues (in Asn-X-Ser/Thr motif) of the nascent growing polypeptide in ER. A first class of high-mannose type $N$-glycans is made after a trimming of Glc and most Man residues. Processing of high-mannose into complex $N$-glycans occurs during the transport of glycoproteins from the cis- (mannose trimming and addition of two GlcNAc residues), through the medial-(addition of the $\beta(1,2)-X y l$ and $\alpha(1,3)$-Fuc on plant, and up to four GlcNAc residues on human $N$-glycans), to the trans-GA (addition of the $\beta(1,3)$-Gal and $\alpha(1,4)-F u c$ on terminal GlcNAc residues of plant, and $\beta(1,4)-G$ al and Neu $5 A$ c on terminal GlcNAc residues of human N-glycans). Differences in the processing of plant and human complex $N$-glycans are late GA maturation events. Modifications of complex into paucimannosidic N-glycans are typical for plant vacuole. 


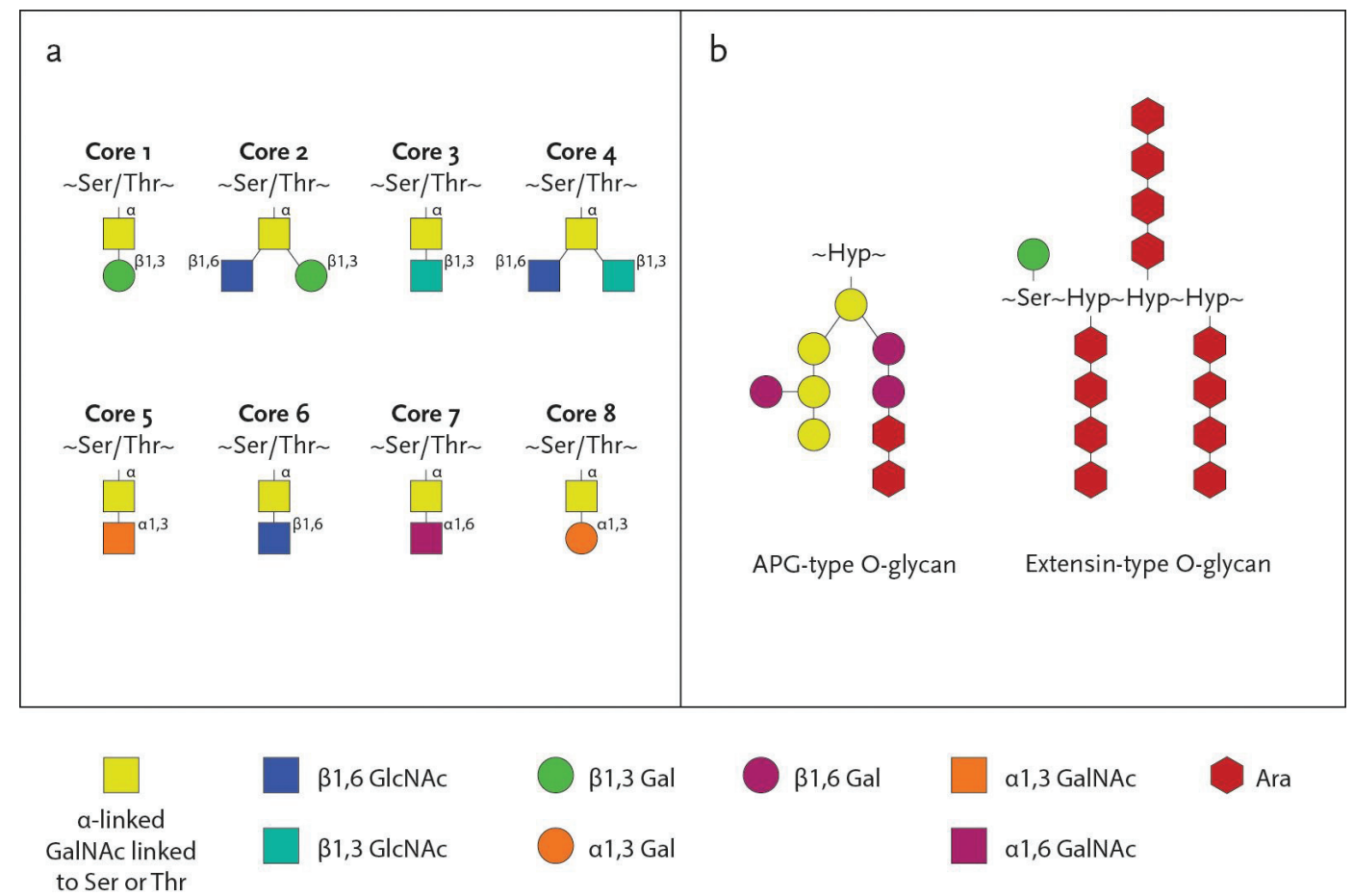

Figure 2. Differences in O-glycan structures between human and plant cells: a) Eight known core structures of mucin-type O-glycans, the most abundant class of $O$-glycosylated proteins in human cells, b) Structures of O-glycans added to Hyp in Hyp-rich glycoproteins (HGRPs), the most abundant and plant-specific class of $O$-glycosylated proteins. Extensins and arabinogalactan proteins (AGPs) are the most common members of this group.

Formation of complex glycans varies between mammals and plants (Figure 1). First, plant-specific complex $\mathrm{N}$-glycans are made by addition of a $\alpha(1,3)$-Fuc and/or $\beta(1,2)$-Xyl by $\alpha(1,3)$-fucosyltransferase (FucT) and $\beta(1,2)$ xylosyltransferase $(\mathrm{XylT})$, respectively $(37,38)$, while animal and human $\mathrm{N}$-glycans have $\alpha$-(1,6)-Fuc attached to the proximal GlcNAc and do not contain any xylose residues (33). Biological relevance of this specific $\alpha(1,3)$ Fuc and/or $\beta(1,2)$-Xyl additions to allergic reactions in humans are not so straightforward and they are still a matter of debate because of regular exposure to plant materials (in this case specific glycans) in our diets and environment; therefore, the potential of allergenicity in humans may be low. However, there are some findings which suggest that typical plant glycoepitopes may induce rapid clearance from circulation and cause a strong allergic reaction because of the presence of $\mathrm{IgE}$ antibodies directed against these epitopes $(22,36)$. Even the mouseproduced monoclonal antibody $(\mathrm{mAb})$ in clinical use, Cetuximab, can trigger anaphylactic reactions in atopic patients by producing $\operatorname{IgE}$ antibodies against non-primate $\mathrm{N}$-glycans (galactose- $\alpha-1,3$-galactose) present on the $\mathrm{Ce}$ tuximab heavy chain (39). Furthermore, mammals have some specific modifications on $\mathrm{N}$-glycans, which do not occur in plants, such as addition of $\beta(1,4)$-galactose (Gal) (40). This limitation can be problematic for production of antibodies since these Gal residues facilitates complement-dependent cytotoxicity and complement binding
(41). In addition, plants lack homologs of mammalian $\mathrm{N}$-acetylglucosaminyltransferase (GnT) -III, -IV and -V (11), which are involved in the addition of GlcNAc residues to create branched $\mathrm{N}$-glycans. As a result, plant $\mathrm{N}$ glycans carry only two antenna structures, while mammalian $\mathrm{N}$-glycans commonly contain multi-antennary glycans with two or more terminal branches (42). These multi-antennary structures are important for increasing the serum half-life of recombinant proteins (11). In plant proteins complex bi-antennary N-glycans have been identified; however, they contain one or two terminal antennae of $\alpha(1,4)$-Fuc and $\beta(1,3)$-Gal linked to the terminal GlcNAc units called Lewis a $\left(\mathrm{Le}^{\mathrm{a}}\right)(43,44,45)$ and are plant-specific glycoepitopes, as we previously mentioned.

Another major drawback of plant $\mathrm{N}$-glycosylation is the lack of sialic (neuraminic) acid (Neu5Ac) on the termini of complex $\mathrm{N}$-glycans, although synthesis of Neu $5 \mathrm{Ac}$ has been documented in some plant species $(46,47)$. Nonexistence of this modification presents an obstacle because addition of Neu5Ac is common in mammalian systems and it is known to be important in preventing clearance of recombinant therapeutic proteins (48). Finally, additional modifications may occur in plants during transport of glycoproteins to their final destinations and this usually involves the trimming of terminal sugars from complex $\mathrm{N}$-glycans, leaving a core glycan with $\alpha(1,3)$-Fuc and/or $\beta(1,2)$-Xyl attached to the Man residue 


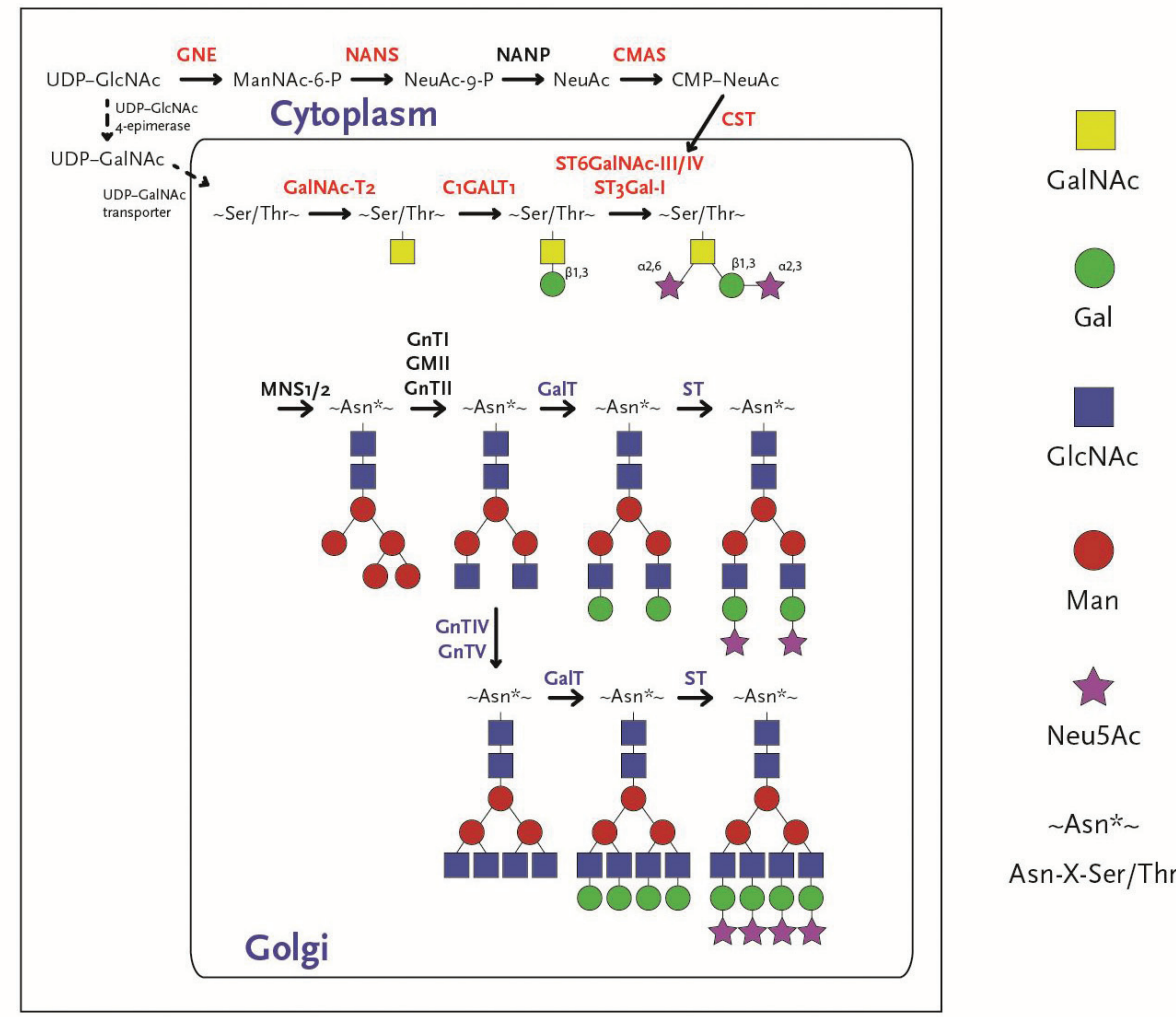

Figure 3. Schematic presentation of the humanized $N$-and $O$-glycosylation pathways in $G A$ of $N$. benthamiana $\triangle X F$ plants obtained by glycoengineering (modified from Strasser (8)). Expression of mammalian $N$-acetylglucosaminyltransferase $I V(G n T I V)$ and $N$-acetylglucosaminyltransferase $V(G n T V)$ is essential for building-up of the multi-antennary complex $N$-glycans (these enzymes are illustrated in blue). Heterologous expressed enzymes for the formation of disialylated $O$-glycans are UDP-N-acetylglucosamine 2-epimerase/ $N$-acetylmannosamine kinase (GNE), $N$-acetylneuraminic acid phosphate synthase (NANS), CMP-N-acetylneuraminic acid synthetase (CMAS) and CMP-Neu5Ac transporter (CST) (these enzymes are illustrated in red). For sialylation of complex $N$-glycans two additional mammalian glycosyltransferases, $\beta 1,4-$ galactosyltransferase (GalT) and $\alpha 2,6$-sialyltransferase (ST), are required (these enzymes are illustrated in blue). Enzymes illustrated in black represent endogenous plant glycosidases and glycoslytransferases that are involved in reactions of early $N$-glycan modification, Golgi- $\alpha$-mannosidase I (MNS1/2), N-acetylglucosaminyltransferase I (GnTI), Golgi- $\alpha$-mannosidase II (GMII) and N-acetylglucosaminyltransferase II (GnTII), as well as enzymes required for conversion and transport of nucleotide sugars for formation of $O$ - and N-glycans, (UDP-GlcNAc 4 epimerase, UDP-GalNAc transporter and Neu5Ac-9-phosphate phosphatase (NANP)).

of the core structure $\mathrm{Man}_{3} \mathrm{GlcNAc}_{2}$. This plant-specific glycans are called paucimannosidic N-glycans, and are commonly found in plant vacuoles (36). In conclusion, plant N-glycans can be classified in four groups: highmannose type, complex type, hybrid type and paucimannosidic type $N$-glycans (for review see Balen and KrsnikRasol 2007(33)).

\section{Modifying N-glycosylation by glycoengineering}

Main goal of glycoengineering in the field of molecular farming is to reduce or eliminate plant-specific Nglycans, and at the same time to introduce mammalianspecific N-glycans. One of the key advantages of plant-specific expression systems is that plants are very tolerant to glycoengineering (23). However, it is important to note that in contrast to the $\mathrm{N}$-glycan profile of mammalian cell-derived recombinant proteins, where a mixture of $\mathrm{N}$-glycans is present, the plant-produced counterparts exhibit generally a largely homogeneous glycosylation profile with a single dominant $\mathrm{N}$-glycan species $(6$, 49, 50). Recombinant proteins that are secreted by plant cells typically carry two types of N-glycans, complex or paucimannosidic type, and glycosylation profile cannot be predicted in advance. Nevertheless, it is known that two factors that can affect this process are (i) final destination of accumulation and route along the secretory pathway and (ii) intrinsic character of the recombinant protein (23). Currently, the mechanisms and effects of both factors are poorly understood and some examples of current knowledge are shown later in the text.

The easiest way is to change intracellular targeting of plant-made recombinant proteins. This was initially used to increase yields of target proteins but, as we mentioned previously, it may also have an effect on the glycosylation state of the protein. The most common approach for ex- 
pression of recombinant proteins in plants is their retention in the ER by addition of C-terminal retention/retrieval signals $(\mathrm{H} / \mathrm{KDEL})(51,52)$ or its extended version (e.g. SEKDEL) (53). Protein retention in ER avoids plantspecific N-glycan maturation ( $\alpha(1,3)$-Fuc and/or $\beta(1,2)$ $\mathrm{Xyl}$ addition) and results in formation of only high-mannose type N-glycans. For example, when recombinant antibody light and heavy chains, produced in transgenic tobacco, were tagged with KDEL sequence they contained exclusively high-mannose $\mathrm{N}$-glycans $(54,55)$. Moreover, Loos et al. reported that a KDEL-tagged antiHIV antibody (2G12) was deposited in protein storage vacuoles that bypass the GA carrying mainly high-mannose $\mathrm{N}$-glycans (56), while Triguero et al. showed that plant-derived mouse IgG mAb, fused to KDEL ER-retention signal, was $\mathrm{N}$-glycosylated homogeneously throughout the plant with mostly high-mannose-type $\mathrm{N}$-glycans (57). Therefore, plant-specific modifications are reduced, consequently reducing induction of allergic reaction. The drawback of this procedure is that protein is susceptible to increased clearance rates and consequently decreased serum half-life (58). Additionally, some studies suggest that fusion of KDEL sequence to the recombinant glycotherapeutic does not always sufficiently reduce plantspecific $\mathrm{N}$-glycans and the process is dependent on the nature of the recombinant protein (36). He et al. showed that when the human enzyme $\alpha$-L-iduronidase (IDUA) was expressed with C-terminal ER-retention sequence (SEKDEL) in Arabidopsis thaliana plants, only a moderate proportion of the recombinant protein was retained in ER and decorated with high mannose $\mathrm{N}$-glycans; the remaining fractions were directed to protein storage vacuoles and contained complex/hybrid type, thus suggesting protein transit through the GA (53). Expression of IDUA with the same ER-retention signal in Brassica napus and tobacco seeds showed that the presence of the SEKDEL sequence greatly diminished the molar ratio of typical plant glycoepitopes, Xyl and Fuc (59). These somewhat contradictory results indicate that the extent of the ERretention of a recombinant protein varies also on the plant species and on the type of cell or tissues used as an expression system $(60)$. Moreover, $\mathrm{N}$-glycosylation pattern of the same plant protein is clearly dependent on the level of plant tissue organization and can be related to the specific developmental status $(45,61,62)$, while oligosaccharide structures of glycoproteins were found be important determinants of plant tissue morphology (63), which indicates that protein trafficking seems to be changing during the plant development $(64,65)$. Therefore, this approach for the production of therapeutic proteins appears very unpredictable.

Targeting of recombinant proteins to other intracellular locations, such as GA, oil bodies, chloroplasts, protein storage bodies or vacuole can also have an effect on the degree and type of $\mathrm{N}$-glycosylation, which can be important for protein function and/or stability (66). For example, $\mathrm{N}$-glycans of paucimannosidic type are often regarded as the most typical for vacuoles, but analysis of proteins that are deposited in vacuoles revealed the possibility of complex and high-mannose types as well. Interestingly, paucimannosidic $\mathrm{N}$-glycans are needed for in vivo efficiency of glucocerebrosidase (GCD), enzyme used in the replacement therapy to cure Gaucher disease. When GCD enzyme was fused with C-terminal vacuolar targeting signal, a recombinant enzyme that carried paucimannosidic $\mathrm{N}$-glycans was produced in transgenic carrot cells (15) and it exhibited enhanced in vivo efficiency compared with currently available drug Cerezyme produced in Chinese hamster ovary $(\mathrm{CHO})$ cells $(67,68)$. Targeting to the vacuole in these glycoengineered cells resulted in more than $90 \%$ of its $\mathrm{N}$-glycans being terminated with Man residues (15). This is very important since Man endings are necessary for the biological uptake of GCD by macrophages, whose lysosomes are deficient for this enzyme in patients treated for Gaucher disease. Food and Drug Administration (FDA) has approved this carrotproduced enzyme, also known as Elelyso ${ }^{\mathrm{TM}}$ in March 2012 for treatment of Gaucher disease in humans and is commercially available in the United States (69). This work is obviously a milestone in industrial production of plantmade recombinant proteins since it is the first and at the moment the only recombinant plant-derived human therapeutic protein approved on the market.Next approach in glycoengineering is to eliminate the addition of plant-specific glycans; specifically $\alpha(1,3)$-Fuc and $\beta(1,2)$ Xyl. This can be done by targeting the genes which encode FucT and XylT enzymes. Strasser et al. generated $A$. thaliana lines in which two genes of the functionally active FucT (FuctA and FuctB) and XylT have been knocked out $(\mathrm{KO})$, and this triple $\mathrm{KO}$ line did not exhibit any phenotypic changes under standard growth conditions (70). Mass spectrometry analysis of N-glycans from endogenous proteins extracted from the triple $\mathrm{KO}$ line failed to detect any $\alpha(1,3)$-Fuc and $\beta(1,2)$-Xyl and glycan composition also became more homogenous since GlcNAc${ }_{2} \mathrm{Man}_{3} \mathrm{GlcNAc}_{2}$ accounted for $42 \%$ of the glycans population. Efficiency was also tested by introducing $\mathrm{mAb}$ against HIV (2G12) into triple $\mathrm{KO}$ and it was shown that this antibody was devoid of $\alpha(1,3)$-Fuc and $\beta(1,2)$-Xyl. The same group of authors used alternative approach by expressing interfering RNA (iRNA) constructs, which targeted the FucT and XylT genes for down-regulation and $>80 \%$ reduction in expression of these genes was achieved (50). Expression of 2G12 mAb in glycoengineered $\Delta \mathrm{XT} / \mathrm{FT}$ Nicotiana benthamiana mutant line, lacking plant-specific glycosylation, exhibited negligible amounts of $\alpha(1,3)$-Fuc and $\beta(1,2)$-Xyl. In addition, significant increase in the homogeneity of glycan composition was achieved, as over $80 \%$ of $\mathrm{N}$-glycans were of a single type, $\mathrm{GlcNAc}_{2} \mathrm{Man}_{3} \mathrm{GlcNAc}_{2}(50)$. Cox et al. have modified the aquatic plant Lemna minor with an RNA interference construct targeting expression of the endogenous genes for FucT and XylT in order to produce a $\mathrm{mAb}$ 
against human $\mathrm{CD} 30$ (14). The resultant $\mathrm{mAbs}$ contained a single major $\mathrm{N}$-glycan species without detectable plantspecific $\mathrm{N}$-glycans and had better antibody-dependent cell-mediated cytotoxicity and effector cell receptor binding activities than $\mathrm{mAbs}$ expressed in cultured $\mathrm{CHO}$ cells. In addition to $\alpha(1,3)$-Fuc and $\beta(1,2)$-Xyl epitopes, many plant species display $\alpha(1,4)$-Fuc and $\beta(1,3)$-Gal linked to terminal GlcNAC, so-called Le ${ }^{a}$ structures (43, 44, 45). Even though $\mathrm{Le}^{\mathrm{a}}$ structures are detected in a much lower proportion on plant $\mathrm{N}$-glycans compared to highly prevailing $\alpha(1,3)$-Fuc and $\beta(1,2)$-Xyl residues $(44,71,72)$, they were still detected in recombinant human erythropoietin (hEPO) expressed in both moss (73) and $N$. benthamiana (74). Since $\mathrm{Le}^{\mathrm{a}}$ epitopes are rarely present in healthy humans and elevated in cancer patients (75) and antibodies against $\mathrm{Le}^{\mathrm{a}}$ are frequent $(76)$, it is advisable to remove respective glycosyltransferases, $\beta(1,3)$ galactosyltransferase and $\alpha(1,4)$-fucosyltransferase, from host plants for production of recombinant proteins. The disruption of galt1 gene resulted in the absence of the complete Le $\mathrm{L}^{\mathrm{a}}$ epitope in the $\mathrm{N}$-glycans of endogenous moss glycoproteins as well as on the moss-produced-hEPO with the remarkable homogeneity in glycosylation (77).

The subsequent step in engineering the plant glycosylation pathway was to introduce mammalian glycotransferases into plants in order to generate recombinant proteins with mammalian-specific $\mathrm{N}$-glycan composition. First attempts introduced the human $\beta 1$,4-galactosyltransferase (GalT), enzyme that adds $\beta$-(1,4)-Gal to the penultimate position of the $\mathrm{N}$-glycan chain, into plants $(78,79)$. In vitro $\beta(1,4)$-galactosylation of a recombinant human antibody in tobacco was to $30 \%$ efficient (80), but due to the overall difference and the heterogeneity of the glycans found in tobacco (81), the mAb could not be considered humanized and represented a complex mixture of different glycoforms. In the next attempt, Bakker et al. (2006) combined introduction of mammalian specific glycotransferases with reduction in levels of plantspecific N-glycans (82). They altered the intracellular location of the recombinant human GalT enzyme by expressing a chimeric gene encoding the cytoplasmic tail, transmembrane domain and stem region (CTS) from $A$. thaliana $\beta(1,2)$-XylT gene located in GA fused to the catalytic domain of human GalT. The results indicated that expression of the hybrid enzyme in tobacco caused high-level galactosylation of $\mathrm{N}$-glycans and a steep decrease in the level of $\mathrm{N}$-glycans with core-bound Xyl and Fuc, presumably due to the premature addition of a terminal sugar in the ER. Second approach applied by Strasser et al. generated a chimeric human GalT fused to the cytoplasmic, transmembrane, and stem (CTS) regions of rat $\alpha(2,6)$-sialyltransferase, which has been used to target proteins to a trans GA in plants (16). This highly active modified version of human $\beta(1,4)$-GalT was used to transform $\triangle \mathrm{XT} / \mathrm{FT} N$. benthamiana line and progeny was screened for efficient protein $\beta(1,4)$-galactosylation. Screening was done in such way that anti-HIV antibodies (2GI and 4E10) were expressed in progeny of transgenic chimeric GalT+ line and $\Delta \mathrm{XT} / \mathrm{FT}$ line. Gal was present on $-80 \%$ of the $\mathrm{N}$-glycans of the anti-HIV antibodies, which were also devoid of $\alpha(1,3)$-Fuc and $\beta(1,2)$-Xyl. However, targeting of Gal-T in different GA compartments can significantly change $\mathrm{N}$-glycosylation of recombinant proteins (83). Namely, incomplete $\mathrm{N}$-glycan processing was reported when human Gal-T were targeted to early/medial GA $(80,82)$, while the amount of galactosylated structures significantly increased when the Gal-T was directed to trans GA compartments (84).

Successful attempts of in planta addition of $\beta(1,4)-\mathrm{Gal}$ to $\mathrm{N}$-glycans represent a step toward terminal sialylation of plant made glycoproteins, since $\beta(1,4)$-Gal residues serve as the acceptor substrate for Neu5Ac. This negatively charged sugar affects the biological activities and half-lives of many therapeutic glycoproteins $(85,86)$. Although sialic acid was detected in some plant species free or protein-bound $(46,47,87)$, the first attempts to facilitate sialylation of endogenous or recombinant proteins in plants were unsuccessful. The reason for that was the fact that plants contain negligible amounts of $\mathrm{Neu} 5 \mathrm{Ac}$ and its activated form, cytidinemonophospho-N-acetylneuraminic acid (CMP-Neu5Ac) $(88,89)$, which is being transferred to a $\beta(1,4)$-Gal-terminus of the complex Nglycan. Castilho et al. performed simultaneous expression in $A$. thaliana plants of three enzymes required for the synthesis of CMP-Neu5Ac in mammals: mouseUDPGlcNAc 2-epimerase/ $\mathrm{N}$-acetylmannosamine kinase (GNE), human $\mathrm{N}$-acetylneuraminic acid phosphatesynthase (NANS), and human CMP-sialic acid synthetase (CMAS), which resulted in the generation of significant amounts of Neu5Ac and CMP-Neu5Ac (90). Furthermore, six enzymes from the mammalian biosynthetic pathway are necessary to achieve substrate biosynthesis, nucleotide sugar activation, transport and Neu5Ac transfer to $\mathrm{N}$-glycans in planta (17). Therefore, six mammalian proteins comprising the sialic acid pathway (GNE, NANS, CMAS, CMP-Neu5Ac transporter (CST) and 2,6-sialyltransferase (ST-Gal)) were co-expressed together with a $\mathrm{mAb}$ in $N$. benthamiana $\Delta \mathrm{XT} / \mathrm{FT}$ transgenic line. Nearly all of the available acceptor substrates (i.e. galactosylated glycans), present in the glycosylation mutants, were sialylated on the Fc domain of the antibody. It was shown that sialylated 2G12 exhibits similar in vitro HIV neutralization potency to other glycoforms derived from plants and $\mathrm{CHO}$ cells, demonstrating full integrity of the protein (17). Moreover, functionally active sialylated hEPO was expressed in $N$. benthamiana plants (91).

Finally, in planta generation of biantennary and multiantennary structures on complex $\mathrm{N}$-glycans has also been achieved. The goal was to express the human $\mathrm{N}$-acetylglucosaminyltransferase genes, mainly $\beta 1,4-$ mannosyl- $\beta 1,4-$ $\mathrm{N}$-acetylglucosaminyltransferase (GnT-III) enzyme that 
is responsible for the addition of bisecting GlcNAc residues to central Man of the core structure, thus creating antennary glycan structures. Additionally, it was important to express $\alpha 1,3$-mannosyl- $\beta 1,4-\mathrm{N}$-acetylglucosaminyltransferase (GnT-IV) and $\alpha 1,6$-mannosyl- $\beta 1,6-\mathrm{N}$ acetylglucosaminyltransferase (GnT-V) that also transfer GlcNAc residues to Man, but the resulting structures are tri- and tetra-antennary $\mathrm{N}$-glycans. Nagels et al. reported production of complex multiantennary $\mathrm{N}$-glycans of endogenous proteins after introduction of GnT-IVa, -IVb and -Va in $\triangle \mathrm{XT} / \mathrm{FT} N$. benthamiana plants, lacking plantspecific N-glycosylation (11). In the following work, GnTIII, -IV and -V were co-expressed in $\triangle \mathrm{XT} / \mathrm{FT} N$. benthamiana plants with the recombinant $\mathrm{hEPO}$ and human transferrin (hTF) (6). This approach resulted in the efficient generation of bisected tetraantennary complex Nglycans without typical plant glycoepitopes on both hEPO and hTF, thus demonstrating generation of recombinant proteins with human-type $\mathrm{N}$-glycosylation at great uniformity.

\section{O-GLYCOSYLATION}

\section{Differences of O-glycosylation between humans and plants}

Linkages in which the sugar is attached to an amino acid containing a hydroxyl group occur in great variety of proteins (92). Therefore, every amino acid with a hydroxyl functional group, serine (Ser), threonine (Thr), tyrosine (Tyr), hydroxylysine (Hyl) or hydroxyproline (Hyp) can be O-glycosylated. O-glycosylation is one of the most complex regulated PTMs, which, dependent on the size and composition of $\mathrm{O}$-glycans, might affect protein conformation and activity (93). In mammals, O-glycosylation is a common post-translational modification of secreted and membrane-bound proteins (94) and it is fundamentally different from $\mathrm{N}$-glycosylation, as a typical consensus amino acid sequence has not been clearly identified yet (95). However, O-glycosylation can influence protein function and structure equally as the $\mathrm{N}$ glycosylation (29). In addition, process is highly regulated and varies depending on tissue type and cell state $(96,97)$. O-glycosylation has been shown to contribute many biological processes in mammals such as inflammation, coagulation, cancer and viral infections. For example, the presence of $\mathrm{O}$-glycans can mask recognition sites for receptors and other interacting proteins or protect them from degradation by proteases (98).

O-glycosylation in humans and plants are significantly different processes, and differences include sites of glycan addition, structure and composition of glycans (Figure 2). In mammals, the most common O-glycosylation sites are Ser and Thr residues decorated with either one sugar molecule such as $\mathrm{N}$-acetylgalactosamine (GalNAc), Fuc, and Gal, or several sugars linked to GalNAc attached to Ser/Thr residues. The most abundant class of O-glyco- slyated proteins are the mucin-type glycoproteins. The highly conserved process of mucin-type glycosylation starts with the addition of GalNAc onto the hydroxyl groups of Ser or Thr, which is performed by enzymes from a multigene family known as $\mathrm{N}$-acetylgalactosaminyltransferases (GalNAc-Ts) located in GA. Unlike co-translational and one-step addition of oligosaccharide precursor on Asn residue in $\mathrm{N}$-glycoslation, in O-glycoslyation additional sugars are added step by step post-translationaly by incorporation of Gal, Fuc, GlcNAc and NeuAc residues in different linkages (99). This process results with complex heterogeneous $\mathrm{O}$-glycans that are classified according to the structure of the glycan core (36), as illustrated in Figure 2A. In principal, plants do not perform GalNAc O-glycosylation (42, 95, 100). Mammalian mucin-type O-glycans have been reported only for rice glutelin (101) and prolamines (102). In plants, O-glycans are commonly attached to hydroxyl group of Ser residues (Solenaceous lectin-type glycosylation), Hyp residues, and rarely $\mathrm{Thr}$ residues. Hydroxylation of Pro residues in ER by prolyl 4-hydroxylase $(\mathrm{P} 4 \mathrm{H})$ is often a prerequisite for protein $\mathrm{O}$-glycosylation in plants and Hyp-rich glycoproteins (HGRPs), in which O-glycans are added to the hydroxyl group of Hyp, are the most abundant class of Olinked plant glycoproteins. Extensins and arabinogalactan proteins (AGPs) (Figure 2B) are the most common members of this group (102). In plants, O-glycosylation process starts in GA with enzymatic addition of Gal or arabinose (Ara). It can be made on contiguous sequences of Hyp (for example Ser-Hyp $_{4}$, when short unbranched Ara-oligosacharides are added, or on clustered non-contiguous Hyp sequences that are decorated with branched arabinogalactan polysaccharides, consisting of $\mathrm{Gal}$ and Ara (36). Much of the recent work on AGPs has focused on their biosynthesis and several of the biosynthetic glycosyltransferase (GT) enzymes responsible for AG polysaccharide production have been identified $(103,104)$ and have been grouped into families based on primary structure (http://www.cazy.org/). Wu et al. (2010), Liang et al. (2013) and Tryfona et al. (2014) identified and cloned two $\alpha$-1,2-fucosyltransferases (FUT4 and FUT6), which are members of the carbohydrate active enzymes (CAZy) GT-37 family (105, 106, 107). Qu et al. (2008) reported a presence of $\beta-1,3$ - galactosyltransferase, a member of GT-31, in the GA of Arabidopsis thaliana (108), while Geshi et al. (2013) have identified an Arabidopsis $\beta$-1,6-galactosyltransferase of the same CAZy family GT-31 (AtGALT31A) that galactosylates AGP side chains and indicated an essential role for AGP proteoglycans in either specification of the hypophysis or orientation of the asymmetric division plane (109). Dilokpimol et al. (2014) identified in Golgi stacks an enzyme from the CAZy family GT-29, AtGALT29A, which is a $\beta-1,6$ galactosyltransferase and can interact with AtGALT31A (110). The complex can work cooperatively to enhance the activities of adding galactose residues 6 -linked to $\beta-1,6$ galactan and to $\beta-1,3$-galactan. These results provided 
new knowledge of the glycosylation process of arabinogalactan proteins and the functional significance of proteinprotein interactions among $\mathrm{O}$-glycosylation enzymes (110). Three $\beta$-1,6-glucuronosyltransferases, the members of glycosyltransferase family 14 (GlcAT14A, GlcAT14B, GlcAT14C), were found to have an important role in the biosynthesis of type II AGP $(111,112)$. Knoch et al. (2013) have characterized a $\beta$-glucuronosyltransferase (AtGlcAT14A) from Arabidopsis thaliana and presented evidence that the enzyme is a glucuronosyltransferase that modifies both the $\beta$-1,6- and $\beta-1,3$-galactan present in type II AGP with a biological role during seedling growth (111). Moreover, Dilokpimol and Geshi (2014) reported the enzyme activities for other two of the Arabidopsis GT14 isoforms, AtGlcAT14B and AtGlcAT14C, which were also found to possess the glucuronosyltransferase activity adding glucuronic acid residues to $\beta-1,3$ - and $\beta$-1,6-linked galactans (112). Gille et al. (2013) identified one member of the GT-77 family, Reduced Arabinose Yariv1 (RAY1), which seems to catalyze the addition of an arabinosyl residue to a side chain containing multiple arabinosyl residues rather than single arabinosyl residues, and therefore may facilitate the synthesis of an extensinlike module in an AGP (113). The authors proposed that $R A Y 1$ encodes a $\beta$-arabinofuranosyltransferase that catalyzes the addition of a $\beta$-arabinofuranose residue onto a $\beta$-galactosyl residue of a Yariv-precipitable wall polymer. In the studies of Basu et al. (2013) and Basu et al. (2015) two hydroxyproline-O-galactosyltransferases (GALT2 and GALT5), which are members of GT-31 and contain a galectin domain, were identified and it was demonstrated that both enzymes are members of a small multigene family and encode Hyp-GALTs (114, 115). Moreover, extensive phenotypic characterization of allelic galt2 and galt 5 single mutants and galt2galt 5 double mutants, which was performed at the biochemical and physiological levels, corroborated the roles of these two enzymes in AG biosynthesis and elucidated the contributions of AG polysaccharides to AGP function. In the recent study, the same group of authors performed the characterization of the remaining GALT members (i.e., GALT1, GALT3, GALT4, and GALT6) of this small six-membered gene family, which are distinguished by encoding a GALT domain as well as a GALECTIN domain (116). Genetic mutant analysis provided additional in vivo evidence that GALT3, GALT4, and GALT6 function as Hyp-GALTs, similar to GALT2 and GALT5. Allelic galt knock-out mutants for all these genes exhibited reduced Hyp-GALT activity and contained considerably less glycosylated AGPs. Moreover, AGP profiling of the galt3, galt4, and galt6 mutants indicated that their activity is not limited to a particular AGP or a small subset of AGPs, but instead broadly acts on co-expressed AGPs (115), similar to that previously reported for galt 2 and galt5 (110). Three other hydroxyproline-O-galactosyltransferases (HPGT1-HPGT3), which are members of GT-31, but lack a galectin domain, were identified by Ogawa-Ohnishi and Matsubayashi (2015) (117).

O-linked glycosylation in plants was found to have roles in plant growth, development, wound healing and plant-microbe interactions. For example, reagents that bind arabinogalactans have effects on the growth of pollen tube tips, somatic embryogenesis and cell expansion and/or division (118) and probably constitute the plant 'homologues' of animal proteoglycans (119). However, unlike N-glycosylation, O-glycosylation is not so well understood in plants and its complexity in plant expression systems remains to be completely elucidated.

\section{Modifying 0-glycosylation by glycoengineering}

Due to significant differences in O-glycosylation between humans and plants as well as to limited number of studies investigating the presence or absence of $\mathrm{O}$-glycans on recombinant plant-made proteins, different approaches to engineering of $\mathrm{O}$-glycosylation have been taken.

Sequence requirements necessary for conversion of Pro residues of mammalian proteins to Hyp residues by plant $\mathrm{P} 4 \mathrm{Hs}$ are not well understood, but studies have shown that plants convert the proline residues to Hyp and attach Ara residues to recombinant proteins $(120,121)$. When peptides of mucin 1 glycoprotein (MUC1) were expressed in $N$. benthamiana, Hyp residues were detected regardless of presence or absence of the $\mathrm{O}$-glycosylation machinery necessary for the transfer of GalNAc (97). It is still unclear whether the Hyp plant-specific glycosylation and mammalian glycosyltransferases compete for neighboring acceptor sites $(97,121,122)$. Immunological potential of plant-specific $\mathrm{O}$-glycosylation in recombinant proteins is poorly understood, although it has been shown that even a single Ara residue linked to Hyp can constitute an IgE binding epitope and provoke allergic reaction (123). This suggests that non-human O-glycans can seriously hinder the broad use of plant-made therapeutics and that their removal would be necessary. To accomplish that, additional studies have to be performed and inactivation of plant $\mathrm{P} 4 \mathrm{H}$ enzyme would be a first logical step. Namely, in silico analysis of human proteome revealed that $30 \%$ of human proteins carry recognition sequence for plant $\mathrm{P} 4 \mathrm{H}$ (36), thus representing potential sites for non-human Prohydroxylation on recombinant protein expressed in plant systems. Recently, several members of the $A$. thaliana $\mathrm{P} 4 \mathrm{H}$ family have been characterized (124), which allows screening for $\mathrm{P} 4 \mathrm{H}$ candidates that hydroxylate specific Pro residues on recombinant glycoproteins in order to eliminate them from expression hosts. Such a strategy very likely requires the elimination of several $\mathrm{P} 4 \mathrm{Hs}$ with overlapping substrate specificities and due to the possible effects on cell wall assembly (124) it might be necessary to perform tissue-specific knockouts or knockdowns to avoid problems with biomass formation and overall 
growth of the plants (94). Besides inactivating $\mathrm{P} 4 \mathrm{Hs}$ expression, another approach would be to block hydroxylation of Pro residues using inhibitors. Moriguchi et al. reported that the ferrous chelator 2,2'-dipyridyl, a potent inhibitor of $\mathrm{P} 4 \mathrm{Hs}$, reduced arabinogalactosylation of endogenous proteins in tobacco seedlings (125). Such a chemical inhibition strategy could be quite useful for transient expression but is less suitable for the stable expression of O-glycosylated recombinant proteins (94).

Besides having their typical O-glycoslyation on Hypresidues, plants in general miss the machinery for production of mammalian-type O-glycosylation (122). Analysis of recombinant hEPO produced in $N$. benthamiana plants failed to show any O-linked GalNAc residues (G), thus suggesting that for initiation of mucin-type $\mathrm{O}$-glycan formation, the corresponding mammalian GalNActransferase that transfers a single GalNAc residue to Ser/ Thr residues has to be expressed in plants. Study by Daskalova et al. investigated the possibility of mimicking mammalian O-glycosylation in plants, specifically the mucin-type addition of GalNAc residues (122). Transgenic $N$. benthamiana plants expressing the human $\mathrm{N}$ acetylgalactosaminyltransferase 2 (GalNAc-T2) enzyme were used, and after enhancing the amount of UDPGalNAc and ensuring its efficient transfer to GA, the majority of model antigen LTB-MUC1 (B subunite of $E$. coli heat labile toxin fused to human mucin 1 glycoprotein) was glycosylated with GalNAc residues. Efficiency was increased by transforming $N$. benthamiana line with UDP-GlcNAc 4-epimerase, a UDP-GlcNAc/UDP-GalNAc transporter and the GalNAc-T2 enzymes. However, authors indicate that recombinant protein may also carry Ara-containing plant-specific O-glycans. In a different study performed on $N$. benthamiana, transient expression of a Pseudomonas aeruginosa Glc(NAc) C4-epimerase and a human polypeptide GalNAc-transferase resulted in GalNAc O-glycosylation of co-expressed human O-glycoprotein substrates (97). However, Hyp modifications observed in a MUC1-based substrate indicated that use of plants for production of recombinant $\mathrm{O}$-glycoproteins requires additional strategies to eliminate the endogenous proline hydroxylases. Yang et al. obtained efficient Gal$\mathrm{NAc} \mathrm{O}$-glycosylation of two stably co-expressed substrate O-glycoproteins in A. thaliana plants and tobacco BY2 cell culture, although a high degree of Pro hydroxylation and Hyp-linked Ara on a mucin-derived substrate was observed (126). Castilho et al. succeeded in an attempt to produce mucin-type O-GalNAc and disialylated core 1 O-linked glycan structures on hEPO in $N$. benthamiana $\triangle \mathrm{XT} / \mathrm{FT}$ transgenic plants by transient expression of human GalNAc-T2, Drosophila melanogaster core $1 \beta$-1,3galactosyltransferase (C1GalT1), human $\alpha 2,3$-sialyltransferase (ST3Gal-I) and Mus musculus $\alpha 2,6$-sialyltransferase (ST6GalNAc-III/IV) along with the machinery for sialylation of $\mathrm{N}$-glycans (127). Moreover, although small amounts of Hyp residues were found on recombinant
EPO, no plant-specific O-glycans were detected. This study demonstrated that $N$. benthamiana plants are eligible candidates for production of recombinant therapeutics with fully humanized $\mathrm{O}$ - and $\mathrm{N}$-glycans (Figure 3).

Interestingly, plant specific O-glycosylation can be used as a tool for enhancing protein stability (increasing serum half-life of recombinant proteins), by providing resistance to proteolytic degradation in vivo and has been proposed as an alternative to the covalent attachment of polyethylene glycol (PEG) to purified proteins (PEGylation). PEGylation is widely used on number of FDAapproved pharmaceuticals because it increases the molecular mass of the proteins and protects them from proteolytic degradation of endogenous proteases. However, PEGylation has some disadvantages: it is time consuming, can result in increased molecular heterogeneity and can negatively affect activity of recombinant proteins in vivo (128). In the several studies, Hyp-glycosylation tag (Hyp-Glyco), which consists of repeating sequences of Ser and Pro residues $\left[(\mathrm{SO})_{n}, \mathrm{n}=2,10\right.$ or 20 and $\left.\mathrm{O}=\mathrm{Hyp}\right]$ (129), was fused to recombinant proteins $(115,116)$. Substantially greater quantities of proteins, with up to 1400 -fold increase in yields, have been reported when the HypGlyco tag was fused with human interferone $\alpha 2 \mathrm{~b}$ (hIFN $\alpha 2 \mathrm{~b})$, enhanced green fluorescent protein (EGFP) and human growth hormone $(130,132,133)$ expressed in BY2 tobacco and Arabidopsis cell culture. Hydroxylation of Pro residues was limited only to Hyp-Glyco tag with variable arabinogalactosylation of each Hyp residue. When hIFN $\alpha 2 \mathrm{~b}$ and human growth hormone were fused with larger tags, $(\mathrm{SO})_{10,20}$, significant increases in the in vivo serum half-life have been reported $(129,133)$. Fusion proteins also retained most of their natural activity, while overall heterogeneity of protein species was significantly lowered compared to heterogeneity following PEGylation (129). The whole impact of internally located plant-specific O-glycans on the stability and biological activity of recombinant proteins is still under investigation. However, a potential advantage of the addition of plant-specific $\mathrm{O}$-glycans via a protein tag is that they may be removed during downstream processing of proteins (23).

\section{The drawbacks of engineering plant glycosylation pathway on plant development}

The absence of any growth phenotype in Arabidopsis cgll mutant, which lacks proper $\mathrm{N}$-glycan maturations because of the defect in Golgi localized GnTI (134), laid the foundation for $\mathrm{N}$-glycan engineering of other species like Nicotiana benthamiana and Lemna minor $(14,50)$, which extended to the O-glysoylation as well $(97,126$, 127). Majority of these studies reported that in glycoengineered plants no obvious changes in phenotype were observed $(14,50,11,127,90)$, thus suggesting that plants tolerate a variety of glycoengineering approaches and are highly convenient for production of glycoproteins with 
humanized glycosylation (135). However, some new findings indicate that unfavorable phenotypical modifications may appear as a result of stable non-native glycosyltransferases expression in transformed plants $(84,136)$. Schneider et al. revealed that $N$. benthaminana and $A$. thaliana transgenic plants that stably express a modified version of human $\beta 1,4$-galactosyltransferase (STGalT) show differences in phenotype (84). Namely, while some transgenic plants grew normally, other lines exhibited stunted growth and developmental retardation even though no differences were observed between their $\mathrm{N}$ glycosylation profiles. Moreover, recent studies from rice reported adverse phenotypes linked with extensive Nglycan remodeling, thus indicating that glycoengineering in some plant species might require new strategies and implementation of more elaborate tools (136). These findings should be taken into consideration in respect to stable glycan engineering in plants and further studies are necessary to investigate in detail the consequences on growth, development, reproduction and stress response of stable engineered plants that carry human-type complex $\mathrm{N}$-glycan modifications.

\section{CONCLUSIONS}

It is now becoming apparent that plants and methods of plant molecular farming offer a powerful expression platform for the production of a variety of recombinant proteins, which show similar, or even higher, biological activity then protein or native homologs in cultured mammalian cells currently used for large-scale production. Substantial achievement has been made in production of plant-made glycoproteins using glycoengineered plant expression systems. As our understanding of structural and functional implications of diverse PTMs increases, we can assume that development of safer and more efficient next-generation biotherapeutics, with optimized glycoforms, will also improve in years to come. Approaches aiming to engineer plant-produced recombinant proteins with enhanced pharmacological properties, although in its infancy, show significant promise. However, the drawbacks of methods applied for engineering plant glycosylation pathway on plant development should also be considered in further studies.

Acknowledgment: Authors wish to thank Mr. Juraj Balen for technical assistance in graphical design of figures.

\section{REFERENCES}

1. DEMAIN AL, VAISHNAV P 2009 Production of recombinant proteins by microbes and higher organisms. Biotechnol Adv 27: 297306. http://dx.doi.org/10.1016/j.biotechadv.2009.01.008

2. KAMIONKA M 2011 Engineering of therapeutic proteins production in Escherichia coli. Curr Pharm Biotechnol 12: 268-74. http://dx.doi.org/10.2174/138920111794295693
3. ROSANO GL, CECCARELLI EA 2014 Recombinant protein expression in microbial systems. Front Microbiol 5: 341. http://dx.doi.org/10.3389/fmicb.2014.00341

4. FRENZEL A, HUST M, SCHIRRMANN T 2013 Expression of recombinant antibodies. Front Immunol 4: 217. http://dx.doi.org/10.3389/fimmu.2013.00217

5. DALTON A C, BARTON W A. Over-expression of secreted proteins from mammalian cell lines. Protein Sci 23: 517-25.

http://dx.doi.org/10.1002/pro.2439

6. CASTILHO A, GATTINGER P, GRASS J, JEZ J, PABST M, ALTMANN F, GORFER M, STRASSER R, STEINKELLNER H $2011 \mathrm{~N}$-glycosylation engineering of plants for the biosynthesis of glycoproteins with bisected and branched complex N-glycans. Glycobiology 21: 813-23.

http://dx.doi.org/10.1093/glycob/cwr009

7. GHADERI D, ZHANG M, HURTADO-ZIOLA N, VARKI A 2012 Production platforms for biotherapeutic glycoproteins. Occurrence, impact, and challenges of non-human sialylation. Biotechnol Genet Eng Rev 28: 147-75. http://dx.doi.org/10.5661/bger-28-147

8. STRASSER R 2013 Engineering of human-type O-glycosylation in Nicotiana benthamiana plants. Bioengineered 4: 191-6. http://dx.doi.org/10.4161/bioe.22857

9. STREATFIELD SJ 2007 Approaches to achieve high-level heterologous protein production in plants, Plant Biotechnol J 5: 2-15. http://dx.doi.org/10.1111/j.1467-7652.2006.00216.x

10. GOMORD V, FAYE L 2004 Posttranslational modification of therapeutic proteins in plants. Curr Opin Plant Biol 7: 171-81. http://dx.doi.org/10.1016/j.pbi.2004.01.015

11. NAGELS B, VAN DAMME EJ, PABST M, CALLEWAERT N, WETERINGS K 2011 Production of complex multiantennary Nglycans in Nicotiana benthamiana plants. Plant Physiol 155: $1103-$ 12. http://dx.doi.org/10.1104/pp.110.168773

12. MA JKC, DRAKE PMW, CHRISTOU P 2003 The production of recombinant pharmaceutical proteins in plants. Nat Rev Genet 4. 794-805. http://dx.doi.org/10.1038/nrg1177

13. OBEMBE OO, POPOOLA JO, LEELAVATHI S, REDDY SV 2011 Advances in plant molecular farming. Biotechnol Adv 29: 21022. http://dx.doi.org/10.1016/j.biotechadv.2010.11.004

14. COX KM, STERLING JD, REGAN JT, GASDASKA JR, FRANTZ KK, PEELE CG, BLACK A, PASSMORE D, MOLDOVAN-LOOMIS C, SRINIVASAN M, CUISON S, CARDARELLI PM, DICKEY LF 2006 Glycan optimization of a human monoclonal antibody in the aquatic plant Lemna minor. Nat Biotechnol 24: 1591-7. http://dx.doi.org/10.1038/nbt1260

15. SHAALTIEL Y, BARTFELD D, HASHMUELI S, BAUM G, BRILL-ALMON E, GALILI G, DYM O, BOLDIN-ADAMSKY SA, SILMAN I, SUSSMAN JL, FUTERMAN AH, AVIEZER D 2007 Production of glucocerebrosidase with terminal mannose glycans for enzyme replacement therapy of Gaucher's disease using a plant cell system, Plant Biotechnol J 5: 579-90. http://dx.doi.org/10.1111/j.1467-7652.2007.00263.x

16. STRASSER R, CASTILHO A, STADLMANN J, KUNERT R, QUENDLER H, GATTINGER P, JEZ J, RADEMACHER T, ALTMANN F, MACH L, STEINKELLNER H 2009 Improved virus neutralization by plant-produced anti-HIV antibodies with a homogeneous beta1,4-galactosylated N-glycan profile. J Biol Chem 284: 20479-85. http://dx.doi.org/10.1074/jbc.M109.014126

17. CASTILHO A, STRASSER R, STADLMANN J, GRASS J, JEZ J, GATTINGER P, KUNERT R, QUENDLER H, PABST M, LEONARD R, ALTMANN F, STEINKELLNER H 2010 In planta protein sialylation through overexpression of the respective mammalian pathway. J Biol Chem 285: 15923-30. http://dx.doi.org/10.1074/jbc.M109.088401 
18. RYBICKI E P 2010 Plant-made vaccines for humans and animals. Plant Biotechnol J 8: 620-37. http://dx.doi.org/10.1111/j.1467-7652.2010.00507.x

19. TREGONING J, MALIGA P, DOUGAN G, NIXON PJ 2004 New advances in the production of edible plant vaccines: chloroplast expression of a tetanus vaccine antigen, TetC. Phytochemistry 65: 989-94. http://dx.doi.org/10.1016/j.phytochem.2004.03.004

20. CABANES-MACHETEAU M, FITCHETTE-LAINÉ AC, LOUTELIER-BOURHIS C, LANGE C, VINE ND, MA JK, LEROUGE P, FAYE L 1999 N-Glycosylation of a mouse IgG expressed in transgenic tobacco plants. Glycobiology 9: 365-72.

21. ELBERS IJ, STOOPEN GM, BAKKER H, STEVENS LH, BARDOR M, MOLTHOFF J W, JORDI WJ, BOSCH D, LOMMEN A 2001 Influence of growth conditions and developmental stage on $\mathrm{N}$-glycan heterogeneity of transgenic immunoglobulin $\mathrm{G}$ and endogenous proteins in tobacco leaves. Plant Physiol 126: 1314-22.

22. BARDOR M, LOUTELIER-BOURHIS C, PACCALET T, COSETTE P, FITCHETTE A C, VÉZINA LP, TRÉPANIER S, DARGIS M, LEMIEUX R, LANGE C, FAYE L, LEROUGE P 2003 Monoclonal C5-1 antibody produced in transgenic alfalfa plants exhibits a $\mathrm{N}$-glycosylation that is homogenous and suitable for glyco-engineering into human-compatible structures. Plant Biotechnol J 1: 451-62.

23. WEBSTER DE, THOMAS MC 2012 Post-translational modification of plant-made foreign proteins; glycosylation and beyond. Biotechnol Adv 30: 410-8.

http://dx.doi.org/10.1016/j.biotechadv.2011.07.015

24. STULEMEIJER IJ, JOOSTEN MH 2008 Post-translational modification of host proteins in pathogen-triggered defence signalling in plants. Mol Plant Pathol 9: 545-60.

http://dx.doi.org/10.1111/j.1364-3703.2008.00468.x

25. BOSCH D, SCHOTS A 2010 Plant glycans: friend or foe in vaccine development? Expert Rev Vaccines 9: 835-42. http://dx.doi.org/10.1586/erv.10.83

26. WALSH G, JEFFERIS R 2006 Post-translational modifications in the context of therapeutic proteins. Nat Biotechnol 24: 1241-52. http://dx.doi.org/10.1038/nbt1252

27. LAUC G, ESSAFI A, HUFFMAN JE, HAYWARD C, KNEZEVIC A, KATTLA JJ, POLAŠEK O, GORNIK O, VITART V, ABRAHAMS JL, PUČIĆ M, NOVOKMET M, REDŽIĆ I, CAMPBELLS, WILD SH, BOROVEČKI F, WANG W, KOLČIĆ I, ZGAGA L, GYLLENSTEN U, WILSON JF, WRIGHT AF, HASTIE ND, CAMPBELL H, RUDD PM, RUDAN I 2011 Genomics meets glycomics - The first GWAS study of human N-glycome identifies hNF1alpha as a master regulator of plasma protein fucosylation, PLoS Genet 6:e1001256. http://dx.doi.org/10.1371/journal.pgen.1001256

28. WALSH G 2010 Post-translational modifications of protein biopharmaceuticals. Drug Discov Today 15: 773-80. http://dx.doi.org/10.1016/j.drudis.2010.06.009

29. LI H, D’ANJOU M 2009 Pharmacological significance of glycosylation in therapeutic proteins.Curr Opin Biotechnol 20: 678-84. http://dx.doi.org/10.1016/j.copbio.2009.10.009

30. SILBERSTEIN S, GILMORE R 1996 Biochemistry, molecular biology, and genetics of the oligosaccharyltransferase. FASEB J 10: 849-58.

31. SCHWARZ F, LIZAK C, FAN YY, FLEURKENS S, KOWARIK M, AEBI M 2011 Relaxed acceptor site specificity of bacterial oligosaccharyltransferase in vivo. Glycobiology 21: 45-54. http://dx.doi.org/10.1093/glycob/cwq130

32. KORNFELD R, KORNFELD S 1985 Assembly of asparaginelinked oligosaccharides. Annu Rev Biochem 54: 631-64. http://dx.doi.org/10.1146/annurev.bi.54.070185.003215
33. BALEN B, KRSNIK-RASOL M 2007 N-glycosylation of recombinant therapeutic glycoproteins in plant systems. Food Technol Biotechnol 45: 1-10.

34. KAUSHAL GP, PASTUSZAK I, HATANAKA K, ELBEIN AD 1990 Purification to homogeneity and properties of glucosidase II from mung bean seedlings and suspension-cultured soybean cells. J Biol Chem 265: 16271-9.

35. MOREMEN KW, TRIMBLE RB, HERSCOVICS A 1994 Glycosidases of the asparagine-linked oligosaccharide processing pathway. Glycobiology 4: 113-25. http://dx.doi.org/10.1093/glycob/4.2.113

36. GOMORD V, FITCHETTE AC, MENU-BOUAOUICHE L, SAINT-JORE-DUPAS C, PLASSON C, MICHAUD D, FAYE L 2010 Plant-specific glycosylation patterns in the context of therapeutic protein production. Plant Biotechnol J 8: 564-87. http://dx.doi.org/10.1111/j.1467-7652.2009.00497.x

37. PRIEM B, GITTI R, BUSH CA, GROSS KC 1993 Structure of ten free $\mathrm{N}$-glycans in ripening tomato fruit. Arabinose is a constituent of a plant N-glycan. Plant Physiol 102: 445-58. http://dx.doi.org/10.1104/pp.102.2.445

38. FITCHETTE-LAINÉ, AC, GOMORD V, CHEKKAFI A, FAYE L 1994 Distribution of xylosylation and fucosylation in the plant Golgi apparatus. Plant J 5: 673-682.

http://dx.doi.org/10.1111/j.1365-313X.1994.00673.x

39. CHUNG CH, MIRAKHUR B, CHAN E, LEQT, BERLIN J, MORSE M, MURPHY BA, SATINOVER SM, HOSEN J, MAURO D, SLEBOS RJ, ZHOU Q, GOLD D, HATLEYT, HICKLIN DJ, PLATTS-MILLS TA 2008 Cetuximab-induced anaphylaxis and IgE specific for galactose-alpha-1,3-galactose. N EnglJ Med 358 1109-17. http://dx.doi.org/10.1056/NEJMoa074943

40. PALACPAC NQ, YOSHIDA S, SAKAI H, KIMURA Y, FUJIYAMA K, YOSHIDA T, SEKI T 1999 Stable expression of human beta1,4-galactosyltransferase in plant cells modifies $\mathrm{N}$-linked glycosylation patterns. Proc Natl Acad Sci USA 96: 4692-7.

41. RAJU TS 2008 Terminal sugars of $\mathrm{Fc}_{\mathrm{C}}$ glycans influence antibody effector functions of IgGs. Curr Opin Immunol 20: 471-8. http://dx.doi.org/10.1016/j.coi.2008.06.007

42. GOMORD V, FAYE L 2004 Posttranslational modification of therapeutic proteins in plants. Curr Opin Plant Biol. 7: 171-81. http://dx.doi.org/10.1016/j.pbi.2004.01.015

43. MELO NS, NIMTZ M, CONRADT HS, FEVEREIRO PS, COSTA J 1997 Identification of the human Lewis(a) carbohydrate motif in a secretory peroxidase from a plant cell suspension culture (Vaccinium myrtillus L.). FEBS Lett 415: 186-91. http://dx.doi.org/10.1016/S0014-5793(97)01121-6

44. FITCHETTE-LAINÉ AC, GOMORD V, CABANES M, MICHALSKI JC, SAINT MACARY M, FOUCHER B, CAVELIER B, HAWES C, LEROUGE P, FAYE L 1997 N-glycans harboring the Lewis a epitope are expressed at the surface of plant cells. Plant Journal 12: 1411-7.

http://dx.doi.org/10.1046/j.1365-313x.1997.12061411.x

45. BALEN B, KRSNIK-RASOL M, ZAMFIR DA, MILOŠEVIĆ J, VAKHRUSHEV SY, PETER-KATALINIĆ J 2006 Glycoproteomic survey of Mammillaria gracillis tissues grown in vitro. J Proteome Res 7; 1658-66. http://dx.doi.org/10.1021/pr0600327

46. SHAH MM, FUJIYAMA K, FLYNN C, JOSHI L 2003 Sialylated endogenous glycoconjugates in plant cells. Nat Biotechnol 21: 1470_ 1. http://dx.doi.org/10.1038/nbt912

47. BALEN B, ZAMFIR A, VAKHRUSHEV SY, KRSNIK-RASOL M, PETER-KATALINIĆ J 2005 Determination of Mammillaria gracillis $\mathrm{N}$-glycan patterns by ESI Q-TOF mass spectrometry. Croat Chem Acta 78: 463-77.

48. STOCKERT E, JÄGER E, CHEN YT, SCANLAN MJ, GOUT I, KARBACH J, ARAND M, KNUTH A, OLD LJ 1998 A survey of the humoral immune response of cancer patients to a panel of human tumor antigens. J Exp Med. 187: 1349-54. http://dx.doi.org/10.1084/jem.187.8.1349 
49. DIRNBERGER D, STEINKELLNER H, ABDENNEBI L, REMY JJ, VAN DE WIEL D 2001 Secretion of biologically active glycoforms of bovine follicle stimulating hormone in plants. Eur $J$ Biochem 268: 4570-9.

http://dx.doi.org/10.1046/j.1432-1327.2001.02384.x

50. STRASSER R, STADLMANN J, SCHAHS M, STIEGLER G, QUENDLER H, MACH L, GLÖSSL J, WETERINGS K, PABST M, STEINKELLNER H 2008 Generation of glyco-engineered Nicotiana benthamiana for the production of monoclonal antibodies with a homogeneous human-like N-glycan structure. Plant Biotechnol J 6: 392-402. http://dx.doi.org/10.1111/j.1467-7652.2008.00330.x

51. GOMORD V, DENMAT LA, FITCHETTE-LAINÉ AC, SATIAT-JEUNEMAITRE B, HAWES C, FAYE L 1997 The C-terminal HDEL sequence is sufficient for retention of secretory proteins in the endoplasmic reticulum (ER) but promotes vacuolar targeting of proteins that escape the ER. Plant J 11: 313-25. http://dx.doi.org/10.1046/j.1365-313X.1997.11020313.x

52. VAN DROOGENBROECK B, CAO J, STADLMANN J, ALTMANN F, COLANESI S, HILLMER S, ROBINSON DG, VAN LERBERGE E, TERRYN N, VAN MONTAGU M, LIANG M, DEPICKER A, DE JAEGER G 2007 Aberrant localization and underglycosylation of highly accumulating single-chain $\mathrm{Fv}-\mathrm{Fc}$ antibodies in transgenic Arabidopsis seeds. Proc Natl Acad Sci USA 104: 1430-5. http://dx.doi.org/10.1073/pnas.0609997104

53. HE X, HASELHORST T, VON ITZSTEIN M, KOLARICH D, PACKER NH, KERMODE AR 2012 Influence of an ER-retention signal on the $\mathrm{N}$-glycosylation of recombinant human $\alpha$-L-iduronidase generated in seeds of Arabidopsis. Plant Mol Biol 79: 157-69. http://dx.doi.org/10.1007/s11103-012-9902-5

54. SRIRAMAN R, BARDOR M, SACK M, VAQUERO C, FAYE L, FISCHER R, FINNERN R, LEROUGE P 2004 Recombinant anti-hCG antibodies retained in the endoplasmic reticulum of transformed plants lack core-xylose and core-alpha(1,3)-fucose residues. Plant Biotechnol J 2: 279-87. http://dx.doi.org/10.1111/j.1467-7652.2011.00638.x

55. PETRUCCELLI S, OTEGUI MS, LAREU F, TRAN DINH O, FITCHETTE AC, CIRCOSTA A, RUMBO M, BARDOR M, CARCAMO R, GOMORD V, BEACHY RN 2006 A KDELtagged monoclonal antibody is efficiently retained in the endoplasmic reticulum in leaves, but is both partially secreted and sorted to protein storage vacuoles in seeds. Plant Biotechnol J 4: 511-27. http://dx.doi.org/10.1111/j.1467-7652.2006.00200.x

56. LOOS A, VAN DROOGENBROECK B, HILLMER S, GRASS J, PABST M, CASTILHO A, KUNERT R, LIANG M, ARCALIS E, ROBINSON DG, DEPICKER A, STEINKELLNER H 2011 Expression of antibody fragments with a controlled $\mathrm{N}$-glycosylation pattern and induction of endoplasmic reticulum-derived vesicles in seeds of Arabidopsis. Plant Physiol 155: 2036-48. http://dx.doi.org/10.1104/pp.110.171330

57. TRIGUERO A, CABRERA G, CREMATA JA, YUEN CT, WHEELER J, RAMÍREZ NI 2005 Plant-derived mouse IgG monoclonal antibody fused to KDEL endoplasmic reticulum-retention signal is $\mathrm{N}$-glycosylated homogeneously throughout the plant with mostly high-mannose-type N-glycans. Plant Biotechnol J 3 : 449-57. http://dx.doi.org/10.1111/j.1467-7652.2005.00137.x

58. KO K, TEKOAH Y, RUDD PM, HARVEY DJ, DWEK RA, SPITSIN S, HANLON CA, RUPPRECHT C, DIETZSCHOLD B, GOLOVKIN M, KOPROWSKI H 2003 Function and glycosylation of plant-derived antiviral monoclonal antibody. Proc Natl Acad Sci USA 100: 8013-8.

http://dx.doi.org/10.1073/pnas.0832472100

59. GALPIN JD, CLEMENS S, KERMODE AR 2010 The carboxyterminal ER-retention motif, SEKDEL, influences the $\mathrm{N}$-linked glycosylation of recombinant human $\alpha$-l-iduronidase but has little effect on enzyme activity in seeds of Brassica napus and Nicotiana tabacum. Plant Sci 178: 440-447.

http://dx.doi.org/10.1016/j.plantsci.2010.02.004
60. DE MUYNCK B, NAVARRE C, BOUTRY M 2010 Production of antibodies in plants: status after twenty years. Plant Biotechnol J 8: 529-63. http://dx.doi.org/10.1111/j.1467-7652.2009.00494.x

61. BALEN B, KRSNIK-RASOL M. ZAMFIR A, ZADRO I, VAKHRUSHEV S, PETER-KATALINIĆ J 2007 Assessment of Nglycan heterogeneity of cactus glycoproteins by one dimensional gel electrophoresis and matrix assisted laser/desorption time-of-flight mass spectrometry. J Biomol Tech 18: 162-172.

62. BALEN B, PEHAREC P, KRSNIK-RASOL M 2008 Developmentally specific soluble and membrane proteins and glycoproteins in Mammillaria gracillis Pfeiff. (Cactaceae) tissue culture. Acta Bot Croat 67: 221-7.

63. PEHAREC ŠTEFANIĆ P, SMOLKO A, HORVATIĆ A, CINDRIĆ M, KRSNIK-RASOL M BALEN B 2013 Protein and glycoprotein patterns related to morphogenesis in horseradish tissue culture. Croat Chem Acta 86: 27-37.

http://dx.doi.org/10.5562/cca2078

64. ARCALIS E, STADLMANN J, MARCEL S, DRAKAKAKI G, WINTER V, RODRIGUEZ J, FISCHER R, ALTMANN F, STOGER E 2010 The changing fate of a secretory glycoprotein in developing maize endosperm. Plant Physiol 153: 693-702. http://dx.doi.org/10.1104/pp.109.152363

65. WANG J, TSE YC, HINZ G, ROBINSON DG, JIANG L 2012 Storage globulins pass through the Golgi apparatus and multivesicular bodies in the absence of dense vesicle formation during early stages of cotyledon development in mung bean. J Exp Bot 63: 1367 80. http://dx.doi.org/10.1093/jxb/err366

66. BOSCH D, CASTILHO A, LOOS A, SCHOTS A, STEINKELLNER H 2013 N-glycosylation of plant-produced recombinant proteins. Curr Pharm Des 19: 5503-12. http://dx.doi.org/10.2174/1381612811319310006

67. STARZYK K, RICHARDS S, YEE J, SMITH SE, KINGMA W 2007 The long-term international safety experience of imiglucerase therapy for Gaucher disease. Mol Genet Metab 90: 157-63. http://dx.doi.org/10.1016/j.ymgme.2006.09.003

68. DEEGAN PB, COX TM 2012 Imiglucerase in the treatment of Gaucher disease: a history and perspective. Drug Des Devel Ther 6 81-106. http://dx.doi.org/10.2147/DDDT.S14395

69. GRABOWSKI GA, GOLEMBO M, SHAALTIEL Y 2014 Taliglucerase alfa: an enzyme replacement therapy using plant cell expression technology. Mol Genet Metab 112: 1-8. http://dx.doi.org/10.1016/j.ymgme.2014.02.011

70. STRASSER R, ALTMANN F, MACH L, GLOSSL J, STEINKELLNER H 2004 Generation of Arabidopsis thaliana plants with complex $\mathrm{N}$-glycans lacking beta1,2-linked xylose and core alpha1,3linked fucose. FEBS Lett 561: 132-6. http://dx.doi.org/10.1016/S0014-5793(04)00150-4

71. KOPRIVOVA A, ALTMANN F, GORR G, KOPRIVA S, RESKI R, DECKER E 2003 N-Glycosylation in the moss Physcomitrella patens is organized similarly to higher plants. Plant Biol 5: 582-591. http://dx.doi.org/10.1055/s-2003-44721

72. STRASSER R, BONDILI JS, VAVRA U, SCHOBERER J, SVOBODA B, GLÖSSL J, LÉONARD R, STADLMANN J, ALTMANN F, STEINKELLNER H, MACH L 2007 A unique beta1,3-galactosyltransferase is indispensable for the biosynthesis of $\mathrm{N}$-glycans containing Lewis a structures in Arabidopsis thaliana. Plant Cell 2007 19: 2278-92. http://dx.doi.org/10.1105/tpc.107.052985

73. WEISE A, ALTMANN F, RODRIGUEZ-FRANCO M, SJOBERG ER, BÄUMER W, LAUNHARDT H, KIETZMANN M, GORR G 2007 High-level expression of secreted complex glycosylated recombinant human erythropoietin in the Physcomitrella Delta-fuc-t Delta-xyl-t mutant. Plant Biotechnol J 5: 389-401. http://dx.doi.org/10.1111/j.1467-7652.2007.00248.x 
74. CASTILHO A, NEUMANN L, GATTINGER P, STRASSER R, VORAUER-UHL K, STEROVSKY T, ALTMANN F, STEINKELLNER H 2013 Generation of biologically active multi-sialylated recombinant human EPO-Fc in plants. PLoS ONE 8:e54836. http://dx.doi.org/10.1371/journal.pone.0054836

75. ZHANG K, BAECKSTRÖM D, HANSSON G C 1994 A secreted mucin carrying Sialyl-Lewis A from colon carcinoma cells binds to E-selectin and inhibits HL-60 cell adhesion. Int J Cancer 59: 823-829. http://dx.doi.org/10.1002/ijc.2910590619

76. WILSON IBH 2001 Identification of a cDNA encoding a plant Lewis-type $\alpha 1$,4-fucosyltransferase. Glycoconj J 18: 439-447. http://dx.doi.org/10.1023/A:1016030000527

77. PARSONS J, ALTMANN F, ARRENBERG CK, KOPRIVOVA A, BEIKE AK, STEMMER C, GORR G, RESKI R, DECKER EL 2012 Moss-based production of asialo-erythropoietin devoid of Lewis A and other plant-typical carbohydrate determinants. Plant Biotechnol J 10: 851-61. http://dx.doi.org/10.1111/j.1467-7652.2012.00704.x

78. PALACPAC NQ, YOSHIDA S, SAKAI H, KIMURA Y, FUJIYAMA K, YOSHIDA T, SEKI T 1999 Stable expression of human beta1,4-galactosyltransferase in plant cells modifies $\mathrm{N}$-linked glycosylation patterns. Proc Natl Acad Sci USA 96: 4692-7.

79. MISAKI R, KIMURA Y, PALACPAC NQ, YOSHIDA S, FUJIYAMA K, SEKI T 2003 Plant cultured cells expressing human beta1,4-galactosyltransferase secrete glycoproteins with galactoseextended N-linked glycans. Glycobiology 13: 199-205. http://dx.doi.org/10.1093/glycob/cwg021

80. BAKKER H, BARDOR M, MOLTHOFF JW, GOMORD V, ELBERS I, STEVENS LH, JORDI W, LOMMEN A, FAYE L, LEROUGE P, BOSCH D 2001 Galactose-extended glycans of antibodies produced by transgenic plants. Proc Natl Acad Sci USA 98: 2899-904. http://dx.doi.org/10.1073/pnas.031419998

81. CABANES-MACHETEAU M, FITCHETTE-LAINÉ AC, LOUTELIER-BOURHIS C, LANGE C, VINE ND, MA JK, LEROUGE P, FAYE L 1999 N-Glycosylation of a mouse IgG expressed in transgenic tobacco plants. Glycobiology 9: 365-72.

82. BAKKER H, ROUWENDAL GJ, KARNOUP AS, FLORACK DE, STOOPEN GM, HELSPER JP, VAN REE R, VAN DIE I, BOSCH D 2006 An antibody produced in tobacco expressing a hybrid beta-1,4-galactosyltransferase is essentially devoid of plant carbohydrate epitopes. Proc Natl Acad Sci USA 103: 7577-82. http://dx.doi.org/10.1073/pnas.0600879103

83. SCHOBERER J, LIEBMINGER E, VAVRA U, VEIT C, CASTILHO A, DICKER M, MARESCH D, ALTMANN F, HAWES C, BOTCHWAY SW, STRASSER R 2014 The transmembrane domain of $\mathrm{N}$-acetylglucosaminyltransferase $\mathrm{I}$ is the key determinant for its Golgi subcompartmentation. Plant J 80: 809-22. http://dx.doi.org/10.1111/tpj.12671

84. SCHNEIDER J, CASTILHO A, PABST M, ALTMANN F, GRUBER C, STRASSER R, GATTINGER P, SEIFERT GJ, STEINKELLNER H 2015 Characterization of plants expressing the human $\beta 1$,4-galactosyltrasferase gene. Plant Physiol Biochem 92: 39-47. http://dx.doi.org/10.1016/j.plaphy.2015.04.010

85. ERBAYRAKTAR S, GRASSO G, SFACTERIA A, XIE QW, COLEMAN T, KREILGAARD M, TORUP L, SAGER T, ERBAYRAKTAR Z, GOKMEN N, YILMAZ O, GHEZZI P, VILLA P, FRATELLI M, CASAGRANDE S, LEIST M, HELBOE L, GERWEIN J, CHRISTENSEN S, GEIST MA, PEDERSEN LØ, CERAMI-HAND C, WUERTH JP, CERAMI A, BRINES M 2003 Asialoerythropoietin is a nonerythropoietic cytokine with broad neuroprotective activity in vivo. Proc Natl Acad Sci USA 100: 6741-6. http://dx.doi.org/10.1073/pnas.1031753100

86. VARKI A 2007 Glycan-based interactions involving vertebrate sialic-acid-recognizing proteins. Nature 446: 1023-1029.

http://dx.doi.org/10.1038/nature05816
87. SHAH MM, FUJIYAMA K, FLYNN CR, JOSHI L 2004 Glycoprotein sialylation in plants? Replay Nat Biotechnol 22: 1352-3. http://dx.doi.org/10.1038/nbt1104-1352

88. SÉVENO M, BARDOR M, PACCALET T, GOMORD V, LEROUGE P, FAYE L 2004 Glycoprotein sialylation in plants? Nat Biotechnol 22: 1351-2. http://dx.doi.org/10.1038/nbt1104-1351

89. ZELENY R, KOLARICH D, STRASSER R, ALTMANN F 2006 Sialic acid concentrations in plants are in the range of inadvertent contamination. Planta 224: 222-7. http://dx.doi.org/10.1007/s00425-005-0206-8

90. CASTILHO A, PABST M, LEONARD R, VEIT C, ALTMANN F, MACH L, GLÖSSL J, STRASSER R, STEINKELLNER H 2008 Construction of a functional CMP-sialic acid biosynthesis pathway in Arabidopsis. Plant Physiol 147: 331-9. http://dx.doi.org/10.1104/pp.108.117572

91. JEZ J, CASTILHO A, GRASS J, VORAUER-UHL K, STEROVSKY T, ALTMANN F, STEINKELLNER H 2013 Expression of functionally active sialylated human erythropoietin in plants. Biotechnol J 8: 371-82. http://dx.doi.org/10.1002/biot.201200363

92. SPIRO RG 2002 Protein glycosylation: nature, distribution, enzymatic formation, and disease implications of glycopeptide bonds. Glycobiology. 12: 43R-56R.

http://dx.doi.org/10.1093/glycob/12.4.43R

93. KODAMA S, TSUJIMOTO M, TSURUOKA N, SUGO T, ENDO T, KOBATA A 1998 Role of sugar chains in the in-vitro activity of recombinant human interleukin 5. Eur J Biochem 211 903-8. http://dx.doi.org/10.1111/j.1432-1033.1993.tb17624.x

94. STRASSER R 2012 Challenges in O-glycan engineering of plants. Front Plant Sci 3: 218. http://dx.doi.org/10.3389/fpls.2012.00218

95. BENNETT EP, MANDEL U, CLAUSEN H, GERKEN TA, FRITZ TA, TABAK LA 2012 Control of mucin-type O-glycosylation: a classification of the polypeptide GalNAc-transferase gene family. Glycobiology 22: 736-56. http://dx.doi.org/10.1093/glycob/cwr182

96. GILL DJ, CHIA J, SENEWIRATNE J, BARD F 2010 Regulation of O-glycosylation through Golgi-to-ER relocation of initiation enzymes. J Cell Biol 189: 843-58. http://dx.doi.org/10.1083/jcb.201003055

97. YANG Z, DREW DP, JØRGENSEN B, MANDEL U, BACH SS, ULVSKOV P, LEVERY SB, BENNETT EP, CLAUSEN H, PETERSEN BL 2012 Engineering mammalian mucin-type O-glycosylation in plants. J Biol Chem 287: 11911-23. http://dx.doi.org/10.1074/jbc.M111.312918

98. MATTU TS, PLEASS RJ, WILLIS AC, KILIAN M, WORMALD MR, LELLOUCH AC, RUDD PM, WOOF JM, DWEK RA 1998 The glycosylation and structure of human serum IgA1, Fab, and Fc regions and the role of $\mathrm{N}$-glycosylation on $\mathrm{Fc} \alpha$ receptor interactions. $J$ Biol Chem 273: 2260-2272. http://dx.doi.org/10.1074/jbc.273.4.2260

99. TARP MA, CLAUSEN H 2008 Mucin-type O-glycosylation and its potential use in drug and vaccine development. Biochim Biophys Acta 1780: 546-63. http://dx.doi.org/10.1016/j.bbagen.2007.09.010

100. SAINT-JORE-DUPAS C, FAYE L, GOMORD V 2007 From planta to pharma with glycosylation in the toolbox. Trends Biotechnol 25: 317-323. http://dx.doi.org/10.1016/j.tibtech.2007.04.008

101. KISHIMOTO T, WATANABE M, MITSUI T, MORI H 1999 Glutelin basic subunits have a mammalian mucin type O-linked disaccharide side chain. Arch Biochem Biophys 370: 271-7. http://dx.doi.org/10.1006/abbi.1999.1406

102. FAYE L, BOULAFLOUS A, BENCHABANE M, GOMORD V, MICHAUD D 2005 Protein modifications in the plant secretory pathway: current status and practical implications in molecular pharming. Vaccine 23: 1770-8. http://dx.doi.org/10.1016/j.vaccine.2004.11.003 
103. TAN L, SHOWALTER AM, EGELUND J, HERNANDEZSANCHEZ A, DOBLIN MS, BACIC A 2012 Arabinogalactanproteins and the research challenges for these enigmatic plant cell surface proteoglycans. Front Plant Sci 3: 1-10. http://dx.doi.org/10.3389/fpls.2012.00140

104. KNOCH E, DILOKPIMOL A, GESHI N 2014 Arabinogalactan proteins: focus on carbohydrate active enzymes. Front Plant Sci 11: 198. http://dx.doi.org/10.3389/fpls.2014.00198

105. WU YY, WILLIAMS M, BERNARD S, DRIOUICH A, SHOOWALTER AM, FAIK A 2010 Functional identification of two nonredundant Arabidopsis $\alpha(1,2)$ fucosyltransferases specific to arabinogalactan proteins. J Biol Chem 285: 13638-45. http://dx.doi.org/10.1074/jbc.M110.102715

106. LIANG Y, BASU D, PATTAHIL S, XU W-L, VENETOS A, MARTIN SL, FAIK A, HAHN MG, SHOWALTER AM 2013 Biochemical and physiological characterization of fut 4 and fut 6 mutants defective in arabinogalactan-protein fucosylation in Arabidopsis. J Exp Bot 64: 5537-51.

http://dx.doi.org/10.1093/jxb/ert321

107. TRYFONA T, THEYS TE, WAGNER T, STOTT K, KEEGSTRA K, DUPREE P 2014 Characterisation of FUT4 and FUT6 $\alpha$-(1 $\rightarrow 2)$-fucosyltransferases reveals that absence of root arabinogalactan fucosylation increases Arabidopsis root growth salt sensitivity. PLoS ONE 9(3): e93291. http://dx.doi.org/10.1371/journal.pone.0093291

108. QU Y, EGELUND J, GILSON PR, HOUGHTON F, GLEESON PA, SCHULTZ CJ, BACIC A 2008 Identification of a novel group of putative Arabidopsis thaliana $\beta$-(1,3)-galactosyl transferases. Plant Mol Biol 68: 43-59. http://dx.doi.org/10.1007/s11103-008-9351-3

109. GESHI N, JOHANSEN JN, DILOKPIMOL A, ROLLAND A, BELCRAM K, VERGER S, KOTAKE T, TSUMURAYA Y, KANEKO S, TRYFONA T, DUPREE P, SCHELLER HV, HÖFTE H, MOUILLE G 2013 A galactosyltransferase acting on arabinogalactan protein glycans is essential for embryo development in Arabidopsis. Plant J 76: 128-37. http://dx.doi.org/10.1111/tpj.12281

110. DILOKPIMOL A, POULSEN CP, VEREB G, KANEKO S, SCHULZ A, GESHI N 2014 Galactosyltransferases from Arabidopsis thaliana in the biosynthesis of type II arabinogalactan: molecular interaction enhances enzyme activity. BMC Plant Biol 4 90. http://dx.doi.org/10.1186/1471-2229-14-90

111. KNOCH E, DILOKPIMOL A, TRYFONA T, POULSEN CP, XIONG G, HARHOLT J, PETERSEN BL, ULVSKOV P, HADI MZ, KOTAKE T, TSUMURAYA Y, PAULY M, DUPREE P, GESHI N 2013 A $\beta$-glucuronosyltransferase from Arabidopsis thaliana involved in biosynthesis of type II arabinogalactan has a role in cell elongation during seedling growth. Plant J76:1016-29. http://dx.doi.org/10.1111/tpj.12353

112. DILOKPIMOL A, GESHI N 2014 Arabidopsis thaliana glucuronosyltransferase in family GT14. Plant Signal Behav 9: e28891. http://dx.doi.org/10.4161/psb.28891

113. GILLE S, SHARMA V, BAIDOO EEK, KEASLING JD, SCHELLER HV, PAULY M 2013 Arabinosylation of a Yarivprecipitable cell wall polymer impacts plant growth as exemplified by the Arabidopsis glycosyltransferase mutant rayl. Mol Plant 6: 1369-72. http://dx.doi.org/10.1093/mp/sst029

114. BASU D, LIANG Y, LIU X, HIMMELDIRK K, FAIK A, KIELISZEWSKI M, HELD M, SHOWALTER AM 2013 Functional identification of a hydroxyproline-O-galactosyltransferase specific for arabinogalactan protein biosynthesis in Arabidopsis. J Biol Chem 288: 10132-43. http://dx.doi.org/10.1074/jbc.M112.432609

115. BASU D, WANG W, MA S, DEBROSSE T, POIRIER E, EMCH K, SOUKUP E, TIAN L, SHOWALTER AM 2015 Two hydroxyproline galactosyltransferases, GALT5 and GALT2, function in arabinogalactan-protein glycosylation, growth and development in Arabidopsis. PLoS ONE 10(5): e0125624.

http://dx.doi.org/10.1371/journal.pone.0125624
116. BASU D, TIAN L, WANG W, BOBBS S, HEROCK H, TRAVERS A, SHOWALTER AM 2015 A small multigene hydroxyproline-O-galactosyltransferase family functions in arabinogalactan-protein glycosylation, growth and development in Arabidopsis. BMC Plant Biol 15: 295. http://dx.doi.org/10.1186/s12870-015-0670-7

117. OGAWA-OHNISHI M, MATSUBAYASHI Y 2015 Identification of three potent hydroxyproline O-galactosyltransferases in Arabidopsis. Plant J 81: 736-46. http://dx.doi.org/10.1111/tpj.12764

118. MAJEWSKA-SAWKA A, NOTHNAGEL EA 2000 The multiple roles of arabinogalactan proteins in plant development. Plant Physiol 122: 3-10. http://dx.doi.org/10.1104/pp.122.1.3

119. WILSON IB 2002 Glycosylation of proteins in plants and invertebrates. Curr Opin Struct Biol 12: 569-77. http://dx.doi.org/10.1016/S0959-440X(02)00367-6

120. KARNOUP AS, TURKELSON V, ANDERSON WH 2005 Olinked glycosylation in maize-expressed human IgA1. Glycobiology. 15: 965-81. http://dx.doi.org/10.1093/glycob/cwi077

121. PINKHASOV J, ALVAREZ ML, RIGANO MM, PIENSOOK K, LARIOS D, PABST M, GRASS J, MUKHERJEE P, GENDLER SJ, WALMSLEY AM, MASON HS 2011 Recombinant plant-expressed tumour-associated MUC1 peptide is immunogenic and capable of breaking tolerance in MUC1.Tg mice. Plant Biotechnol J 9: 991-1001. http://dx.doi.org/10.1111/j.1467-7652.2011.00614.x

122. DASKALOVA SM, RADDER JE, CICHACZ ZA, OLSEN SH, TSAPRAILIS G, MASON H, LOPEZ L C 2010 Engineering of $N$. benthamiana plants for production of $\mathrm{N}$-acetylgalactosamineglycosylated proteins - towards development of a plant-based platform for production of protein therapeutics with mucin type Oglycosylation. BMC Biotechnol 10: 62. http://dx.doi.org/10.1186/1472-6750-10-62

123. LÉONARD R, PETERSEN BO, HIMLY M, KAAR W, WOPFNER, N, KOLARICH D, VAN REE R, EBNER C, DUUS J $\varnothing$, FERREIRA F, ALTMANN F 2005 Two novel types of O-Glycans on the mugwort pollen allergen Art v 1 and their role in antibody binding. J Biol Chem 280: 7932-40. http://dx.doi.org/10.1074/jbc.M410407200

124. VELASQUEZ SM, RICARDI MM, DOROSZ JG, FERNANDEZ PV, NADRA AD, POL-FACHIN L, EGELUND J, GILLE $S$, HARHOLT J, CIANCIA M, VERLI H, PAULY M, BACIC A, OLSEN CE, ULVSKOV P, PETERSEN BL, SOMERVILLE C, IUSEM ND, ESTEVEZ JM 2011 O-glycosylated cell wall proteins are essential in root hair growth. Science 332: 1401-3. http://dx.doi.org/10.1126/science.1206657

125. MORIGUCHI R, MATSUOKA C, SUYAMA A, MATSUOKA K 2011 Reduction of plant-specific arabinogalactan-type O-glycosylation by treating tobacco plants with ferrous chelator 2,2'-dipyridyl. Biosci Biotechnol Biochem 75: 994-6. http://dx.doi.org/10.1271/bbb.100884

126. YANG Z, BENNETT EP, JØRGENSEN B, DREW DP, ARIGI E, MANDEL U, ULVSKOV P, LEVERY SB, CLAUSEN H, PETERSEN BL 2012b Toward stable genetic engineering of human O-glycosylation in plants. Plant Physiol 160: 450-63. http://dx.doi.org/10.1104/pp.112.198200

127. CASTILHO A, NEUMANN L, DASKALOVA S, MASON HS, STEINKELLNER H, ALTMANN F, STRASSER R 2012 Engineering of sialylated mucin-type O-glycosylation in plants, J Biol Chem 287: 36518-26. http://dx.doi.org/10.1074/jbc.M112.402685

128. HARRIS JM, CHESS RB 2003 Effect of pegylation on pharmaceuticals. Nat Rev Drug Discov 2: 214-21. http://dx.doi.org/10.1038/nrd1033

129. XU J, TAN L, GOODRUM KJ, KIELISZEWSKI MJ 2007 Highyields and extended serum half-life of human interferon alpha2b expressed in tobacco cells as arabinogalactan-protein fusions. Biotechnol Bioeng 97: 997-1008. http://dx.doi.org/10.1002/bit.21407 
130. KIELISZEWSKI MJ, XU J 2006 Methods of producing peptides/ proteins and peptides/proteins produced thereby. United State Patent, Publication No. US 2006; 20060026719.

131. XU X, GAN Q, CLOUGH RC, PAPPU KM , HOWARD JA, BAEZ JA, WANG K 2011 Hydroxylation of recombinant human collagen type I alpha 1 in transgenic maize co-expressed with a recombinant human prolyl 4-hydroxylase. BMC Biotechnol 11: 69. http://dx.doi.org/10.1186/1472-6750-11-69

132. XU J, TAN L, LAMPORT DT, SHOWALTER AM, KIELISZEWSKI MJ 2008 The O-Hyp glycosylation code in tobacco and Arabidopsis and a proposed role of Hyp-glycans in secretion. Phytochemistry 69: 1631-40.

http://dx.doi.org/10.1016/j.phytochem.2008.02.006

133. XU J, OKADA S, TAN L, GOODRUM KJ, KOPCHICK JJ, KIELISZEWSKI MJ 2010 Human growth hormone expressed in tobacco cells as an arabinogalactan-protein fusion glycoprotein has a prolonged serum life. Transgenic Res 19: 849-67. http://dx.doi.org/10.1007/s11248-010-9367-8

134. VON SCHAEWEN A, STURM A, O'NEILL J, CHRISPEELS M 1993 Isolation of a mutant Arabidopsis plant that lacks N-acetyl glucosaminyl transferase I and is unable to synthesize Golgi-modified complex N-linked glycans. Plant Physiol 102: 1109-1118. http://dx.doi.org/10.1104/pp.102.4.1109

135. LOOS A, STEINKELLNER H 2014 Plant glyco-biotechnology on the way to synthetic biology. Front Plant Sci 5: 523. http://dx.doi.org/10.3389/fpls.2014.00523

136. STRASSER R 2014 Biological significance of complex N-glycans in plants and their impact on plant physiology. Front Plant Sci 5: 363. http://dx.doi.org/10.3389/fpls.2014.00363 